\title{
Results of Simulated Abnormal Heating Events for Full-length Nuclear Fuel Rods
}

January 1983

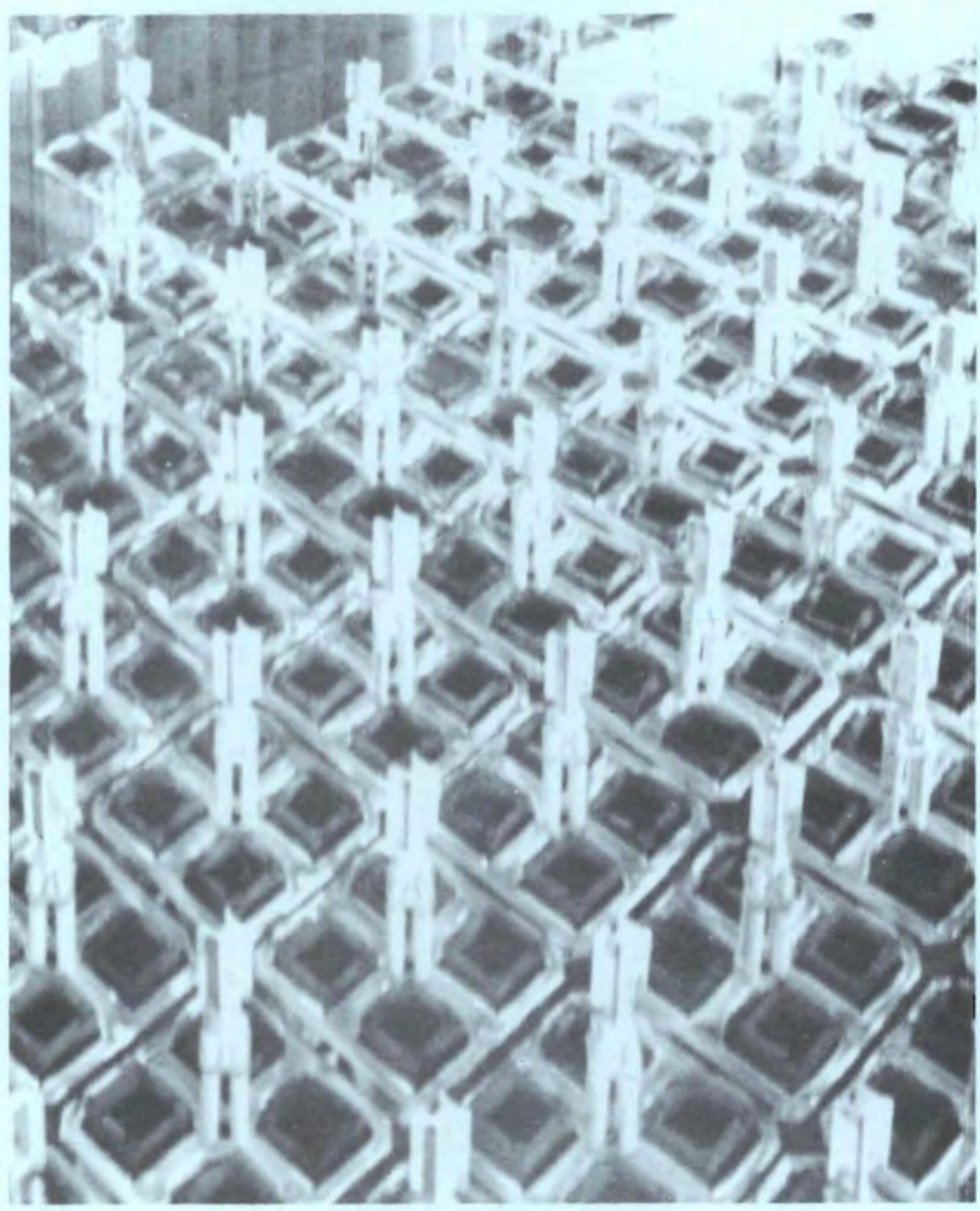

Prepared for the U.S. Department of Energy under Contract DE-AC06-76RLO 1830

Pacific Northwest Laboratory

Operated for the U.S. Department of Energy by Battelle Memorial Institute 


\title{
DISCLAIMER
}

This report was prepared as an account of work sponsored by an agency of the United States Government. Neither the United States Government nor any agency thereof, nor any of their employees, makes any warranty, express or implied, or assumes any legal liability or responsibility for the accuracy, completeness, or usefulness of any information, apparatus, product, or process disclosed, or represents that its use would not infringe privately owned rights. Reference herein to any specific commercial product, process, or service by trade name, trademark, manufacturer, or otherwise, does not necessarily constitute or imply its endorsement, recomme-idation, or favoring by the United States Government or any agency thereof. The views and opinions of authors expressed herein do not necessarily state $\mathrm{cr}$ reflect those of the United States Government or any agency thereof.

\author{
PACIFIC NORTHWEST I.ABORATORY \\ operated by \\ BATTELLE \\ for the \\ UNITED STATES DEPARTMENT OF ENERGY \\ under Contract DE-AC06-76RLO 1830
}

\begin{tabular}{|c|c|}
\hline \multicolumn{2}{|c|}{ Printed in the United States of America } \\
\hline \multicolumn{2}{|c|}{$\begin{array}{c}\text { Available from } \\
\end{array}$} \\
\hline \multicolumn{2}{|c|}{ National Technical Information Service } \\
\hline \multicolumn{2}{|c|}{ United States Department of Commerce } \\
\hline \multirow{2}{*}{\multicolumn{2}{|c|}{$\begin{array}{c}5285 \text { Port Roval Road } \\
\text { Springfield, Virginia } 22151\end{array}$}} \\
\hline & \\
\hline \multirow{2}{*}{\multicolumn{2}{|c|}{$\begin{array}{l}\text { NTIS Price Codes } \\
\text { Microfiche A01 }\end{array}$}} \\
\hline & \\
\hline \multicolumn{2}{|c|}{ Printed Copy } \\
\hline & Price \\
\hline Pages & Codes \\
\hline 001-025 & A02 \\
\hline 026-050 & $\mathrm{A} 03$ \\
\hline 051-075 & A04 \\
\hline $076-100$ & A05 \\
\hline $10 \div-125$ & A06 \\
\hline $126-150$ & A 07 \\
\hline $151-175$ & A08 \\
\hline $176-200$ & $\mathrm{~A} 09$ \\
\hline $201-225$ & A 010 \\
\hline $226-250$ & A011 \\
\hline $251-275$ & A012 \\
\hline $276-300$ & A 013 \\
\hline
\end{tabular}




\title{
33679000590028
}

PNL -4555

UC-85

\begin{abstract}
RESULTS OF SIMULATED ABNORMAL
HEATING EVENTS FOR FULL-LENGTH NUCLEAR FUEL RODS
\end{abstract}

R. J. Guenther

January 1983

Prepared for

the U.S. Department of Energy

under Contract DE-AC06-76RLO 1830

Pacific Northwest Laboratory

Richland, Washington 99352 
b 


\section{ACKNOWLEDGMENTS}

This report summarizes work conducted for the U.S. Department of Energy under contract DE-AC06-76RL0 1830. The support and guidance of R. D. Nelson, A. B. Johnson, Jr., and E. R. Gilbert are greatly appreciated. Appreciation is also extended to R. F. Klein and J. P. Pilger for design and fabrication of the test rods and test can; to G. S. Allison, G. E. Bigelow, and L. E. Barnett for furnace modification and testing; to R. K. Marshall and R. A. Scoggin for test instrumentation; to R. H. Beauchamp for metallography; to W. J. Bailey for assistance during testing; to $W$. J. Bennett for preparing the test data for plotting and analysis; and to S. K. Edler for editorial assistance. 


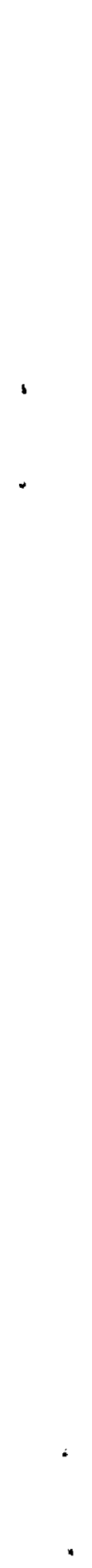




\section{ABSTRACT}

Full-length nuclear fuel rods were tested in a furnace to simulate the slow heating rates postulated for commercial pressurized water reactor fuel rods exposed to an overheating event in a storage cask. Fuel rod temperatures and internal gas pressures were monitored during the test and are presented along with mensural data for the cladding. Metallography of the cladding provided data on grain growth, hydriding, oxidation, cladding stresses, and the general nature of the failures. 
, 


\section{SUMMARY AND CONCLUSIONS}

Furnace tests were conducted on full-length unirradiated pressurized water reactor (PWR) fuel rods to determine the effect and importance of slow heating rates on the deformation of commercial PWR rods. The results indicate that the heating rate significantly affects cladding deformation and failure pressure. At lower heating rates, failure pressures decrease because cladding deformation over the entire length of the rod is greater than for faster heating rates.

The rods in these tests failed at tiny (up to $150-1 \mathrm{~m}$ ) axial cracks located at regions where the diametral cladding strain was $\sim 100 \%$. The general degree of ballooning depended on heating rate. Because the fuel rods were tested in a horizontal position, they sagged $\sim 0.75 \mathrm{~cm}(0.3 \mathrm{in.})$ at the middle of the span between the Inconel spacers.

Metallographic examination of cladding specimens from the failed fuel rods provided several results concerning cladding stresses, grain growth, hydride orientations, and surface oxidation.

- The cladding stresses at the point and time of failure were slightly lower for furnace-tested rods than for rods heated at faster rates.

- There was a direct correlation between heating rate and increased grain size; however, the most significant grain growth occurred at the failure regions where cladding strains were the greatest.

- At the beginning of the test, cladding hydrides were primarily circumferentially oriented. As a result of the tests, the hydride platelets increased in size, decreased in number, and became slightly more radially oriented. Cladding failure was not associated with hydriding; the cladding ruptured by duçtile failure at a site with extensive grain growth.

- Oxidation did not play a part in the failure of these fuel rods tested in limited air. The thickness of the oxide layer increased up to 10 um with time for temperatures above $600^{\circ} \mathrm{C}$; and circumferential cracks, which were dependent on diametral strain, formed in the oxide layer. 
These results indicate the importance of heating rate on cladding microstructure and failures.

In overheating events involving rates of $60^{\circ} \mathrm{C} / \mathrm{h}$ or lower, several hours are required to reach cladding failure conditions, thus providing a significant response time. More importantly, such heating rates/ would result in very small cracks in the cladding and probably would not result in significant dispersion of radioactive particles. 


\section{CONTENTS}

ACKNOWLEDGMENTS. ......................................

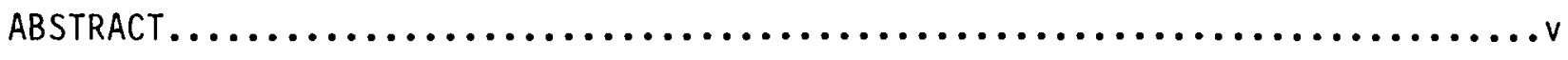
SUMMARY AND CONCLUSIONS.....................................

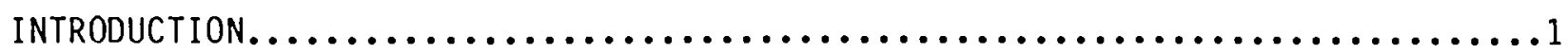

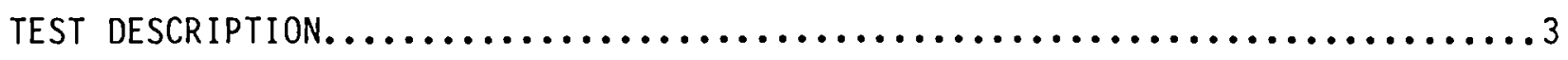

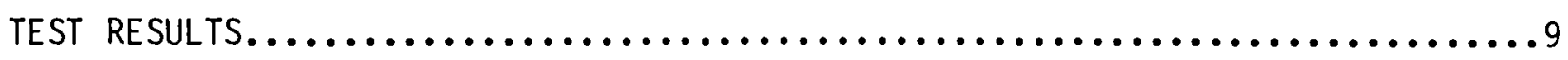

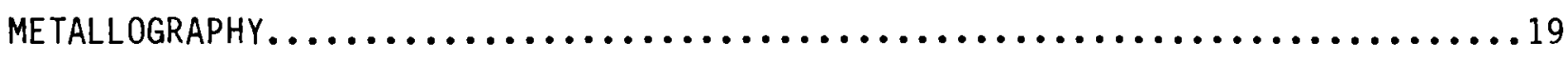

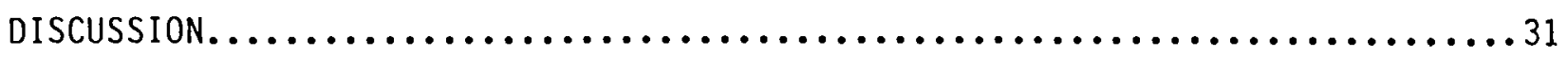

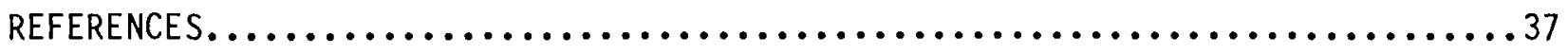




\section{FIGURES}

1 Pretest Photographs of Several Portions of the Test Rods............4

2 Location of Thermocouples on Dummy Rod.........................

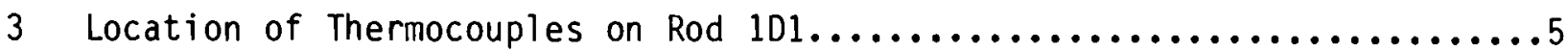

4 Location of Thermocouples on Rods $4 \mathrm{Fl}$ and $T 3 \ldots \ldots \ldots \ldots \ldots \ldots \ldots \ldots$

5 Arrangement of Test Equipment During Furnace Testing...............6

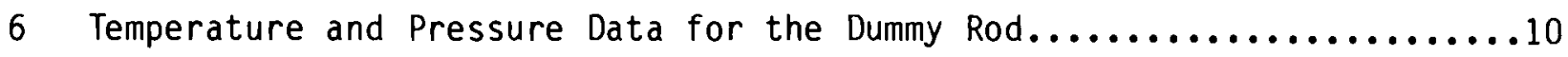

7 Temperature and Pressure Data for Rod $101 \ldots \ldots \ldots \ldots \ldots \ldots \ldots \ldots \ldots \ldots$

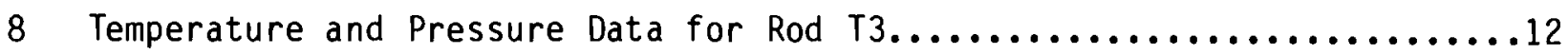

9 Temperature and Pressure Data for Rod $4 F 1 \ldots \ldots \ldots \ldots \ldots \ldots \ldots \ldots \ldots$

10 Rods 101 and $4 \mathrm{~F} 1$ After Testing at $\sim 53^{\circ} \mathrm{C} / \mathrm{h}$ and $\sim 10^{\circ} \mathrm{C} / \mathrm{h}$, Respectively, Compared with Enlargement of Failure Site in Rod 1D1.....15

11 Rod T3 After Testing at $\sim 40^{\circ} \mathrm{C} / \mathrm{h}$ Compared with Enlargement of

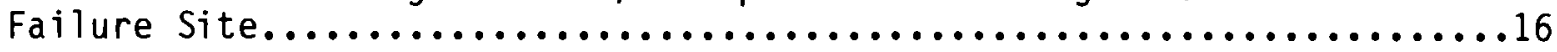

12 Rods 101 and $4 \mathrm{~F} 1$ After Testing at $\sim 53^{\circ} \mathrm{C} / \mathrm{h}$ and $\sim 10^{\circ} \mathrm{C} / \mathrm{h}$, Respectively, Compared with Enlargement of Failure Site in Rod 4F1.....17

13 Comparison of Cladding Diameters and Thicknesses at Several Locations

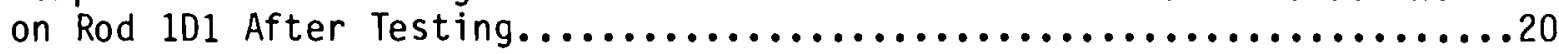

14 Comparison of $\mathrm{Cl}$ adding Diameters and Thicknesses at Two Locations

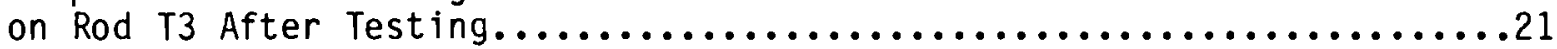

15 Comparison of $\mathrm{Cladding} \mathrm{Diameters} \mathrm{and} \mathrm{Thicknesses} \mathrm{at} \mathrm{Several} \mathrm{Locations}$

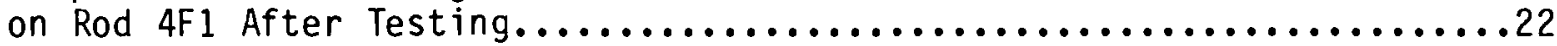

16 Transverse Sections Showing Grain Structure in Rod 1D1..............23

17 Transverse Sections Showing Grain Structure in Rod T3...............25

18 Transverse Sections Showing Grain Structure in Rod $4 F 1 \ldots \ldots \ldots \ldots . . . . .26$

19 Variation in Grain Size for Different Cladding Thicknesses in

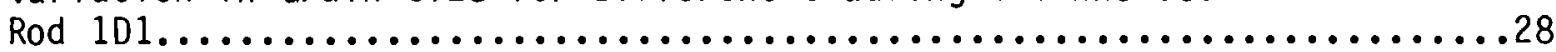

20 Transverse Sections Showing Hydride Changes in Rod 1D1..............29

21 Cladding Oxidation at Typical Locations Compared with Cladding

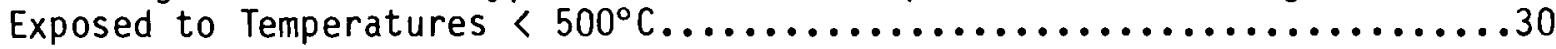


22 Failure Pressures and Temperatures for Fast and Slow Heating Rates......32

23 Failure Temperatures and Stresses for Fast and Slow Heating Rates......33

24 Rod 5C from the MT-3 Experiment in the NRU Loss-of-Coolant Tests.......34

25 Exposed Fuel in Test Fuel Bundle After NRU LOCA Test MT-2 Compared

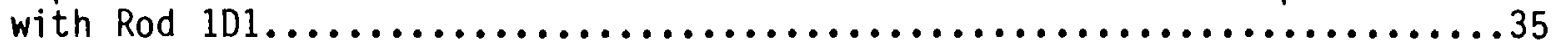

26 Comparison of the Cladding Diametral Strain in Rod $5 C$ of the NRU LOCA Tests with Those in Rods 1D1, T3, and $4 \mathrm{~F} 1 \ldots \ldots \ldots \ldots \ldots \ldots \ldots \ldots \ldots$ 
TABLES

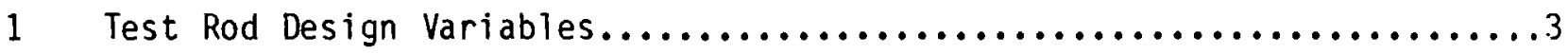

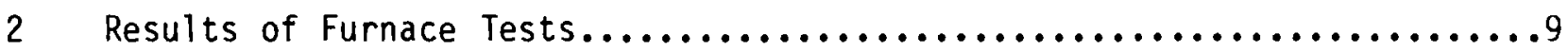

3 Comparison of Thermal and Mechanical Effects on Grain Size...........27 


\section{INTRODUCTION}

Furnace tests of full-length unirradiated pressurized water reactor (PWR) rods were conducted by Pacific Northwest Laboratory (PNL) (a) for the Commercial Spent Fuel Management (CSFM) program, which is sponsored by the U.S. Department of Energy (DOE). The CSFM program is charged with carrying out the mandate of the Nuclear Waste Policy Act of 1982 relating to storage of spent nuclear fuel and providing technical assistance to utilities for managing commercial spent fuel for nuclear power plants. A significant part of that goal is being achieved through investigations on wet and dry storage of spent nuclear fuel rods. The furnace tests described in this report were undertaken to support those investigations by providing measured data for full-length unirradiated fuel rods exposed to a thermal environment that is postulated for a fire involving storage casks containing up to 24 PWR or 52 boiling water reactor (BWR) fuel assemblies.

The furnace tests were performed at very slow heating rates (10 to $\left.60^{\circ} \mathrm{C} / \mathrm{h}\right)^{(\mathrm{b})}$ that were chosen to approximate the expected temperature rise during a hypothetical cask fire with a peak temperature of $800^{\circ} \mathrm{C}$. Shipping casks are designed to withstand a 30 -min $800^{\circ} \mathrm{C}$ fire and have been tested at temperatures up to $1150^{\circ} \mathrm{C}$. (2) The probability and characteristics of a storage cask fire are not yet defined; however, the peak temperatures could be the same in storage and shipping casks although storage casks would have lower heatup rates because of their larger size. The actual rate of temperature increase at the fuel rods in a fuel assembly would be a complex function of the ambient conditions, the heat transfer characteristics of the specific cask, and the design and configuration of the fuel rods within the fuel assembly. Thus, the heating rates for these tests were chosen to cover a range of expected heating rates.

This document describes the test equipment and procedures, results of the test, and metallographic data.

(a) Operated for DOE by Battelle Memorial Institute.

(b) Heating rates of $28^{\circ} \mathrm{C} / \mathrm{s}$ (which is $\sim 1700$ times the rate used in these tests) are typical in tests simulating LOCAs. (1) 
'

. 
The fuel rods used in the furnace tests were of commercial PWR design as indicated in Table 1. Each rod had void volumes equivalent to typical commercial fuel rods and contained $3 \%$-enriched $\mathrm{UO}_{2}$ fuel, except for the dummy rod, which contained a stainless steel rod instead of fuel. The void volume included the free volume of the pressure sensor and the capillary tube that connected the plenum of the rod to the pressure sensor--the plenum length was shortened slightly to provide a typical void volume.

Sections from an Inconel grid spacer (see Figure 1) simulated the constraint from the grid spacer in a fuel assembly. Each fuel rod had seven spacers located $53.3 \mathrm{~cm}$ (21 in.) apart.

Chromel/alumel thermocouples (TCS) with magnesium oxide insulation and Inconel sheathing were placed at several locations on the cladding and the grid spacers during the first test, which was conducted using the dummy rod. The TCs were positioned to compare those temperatures measured on the cladding and those measured on or near the spacers. The cladding TCs were not welded to the cladding because of the formation of a eutectic between zirconium and nickel at $\sim 960^{\circ} \mathrm{C}$. Niobium foil was placed between the tips of the TCs and the cladding to further prevent any eutectic formation during the test with the dummy rod, which had TCS wire wrapped to the cladding. On the remaining test rods, the TCs were placed on only the spacers because it was determined that the temperature difference between the cladding and the spacers was small. Figures 2, 3, and 4 indicate the location of TCs on the test rods.

\section{TABLE 1. Test Rod Design Variables}

Cladding material

Uitimate tensile strength at $20^{\circ} \mathrm{C}$

Cladding outside diameter

Cladding inside diameter

Fuel pellet diameter

Active fuel length

Helium pressurization at $25^{\circ} \mathrm{C}$

Void volume (excluding fuel porosity)
Zircaloy -4

$738 \mathrm{MPa}(107,000 \mathrm{psi})$

$0.963 \mathrm{~cm}(0.379$ in. $)$

$0.841 \mathrm{~cm}(0.331 \mathrm{in.})$

$0.826 \mathrm{~cm}(0.325 \mathrm{in.})$

$365.76 \mathrm{~cm}$ (144 in.)

$3.4 \mathrm{MPa}$ (500 psig)

$23 \mathrm{~cm}^{3}\left(1.4 \mathrm{in}^{3}\right)$ 


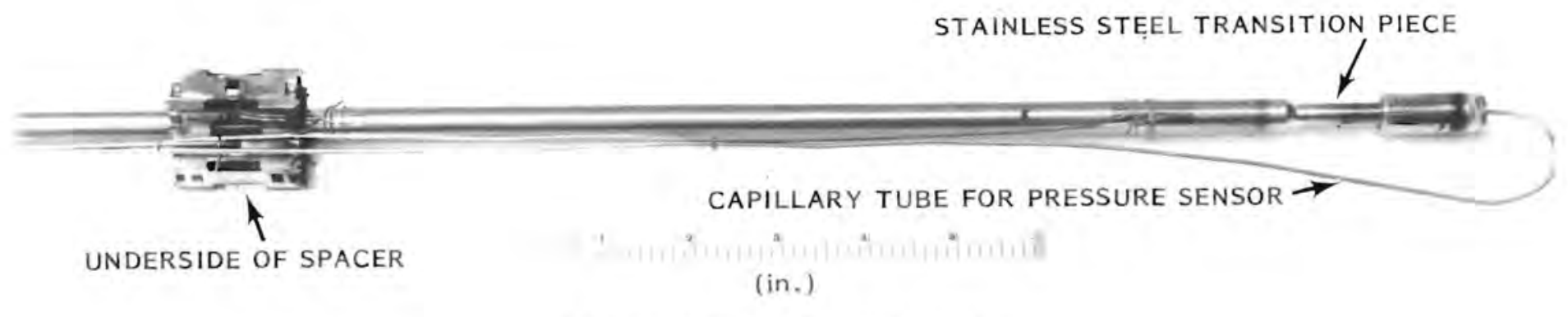

(a) UPPER END OF DUMMY ROD

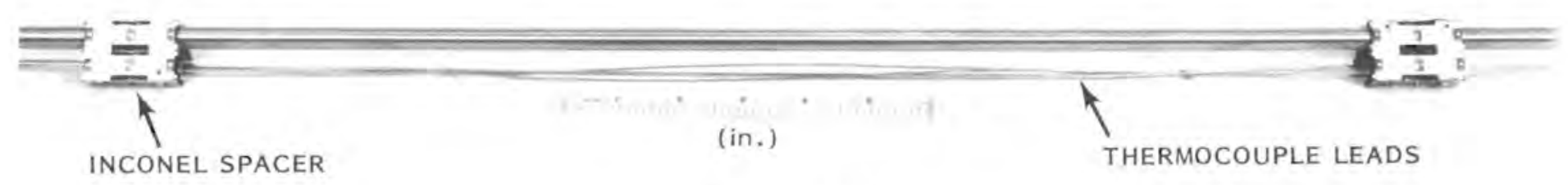

(b) TYPICAL SPAN

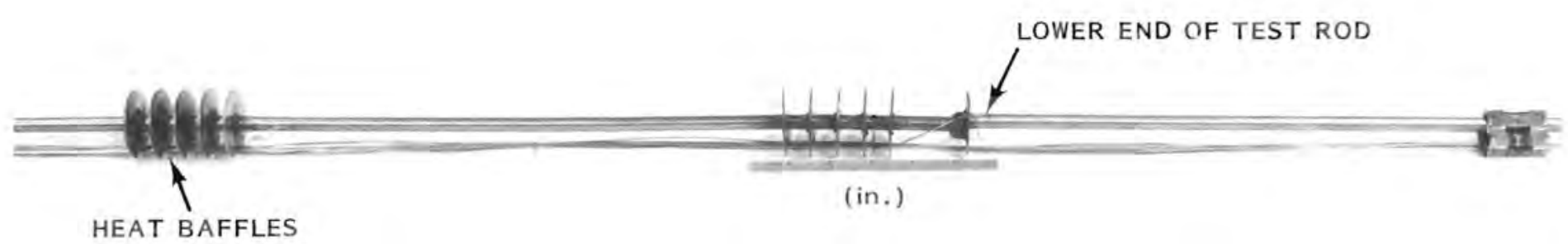

(c) LOWER END OF TEST ROD

FIGURE 1. Pretest Photographs of Several Portions of the Test Rods 


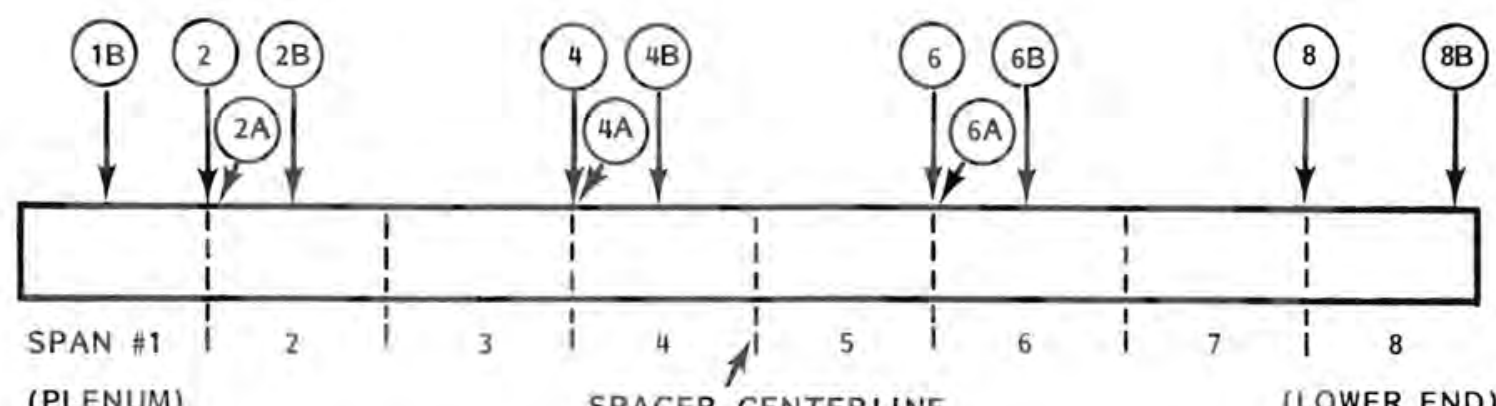

(PLENUM)

SPACER CENTERLINE

(LOWER END)

FIGURE 2. Location of Thermocouples on Dummiy Rod(a)

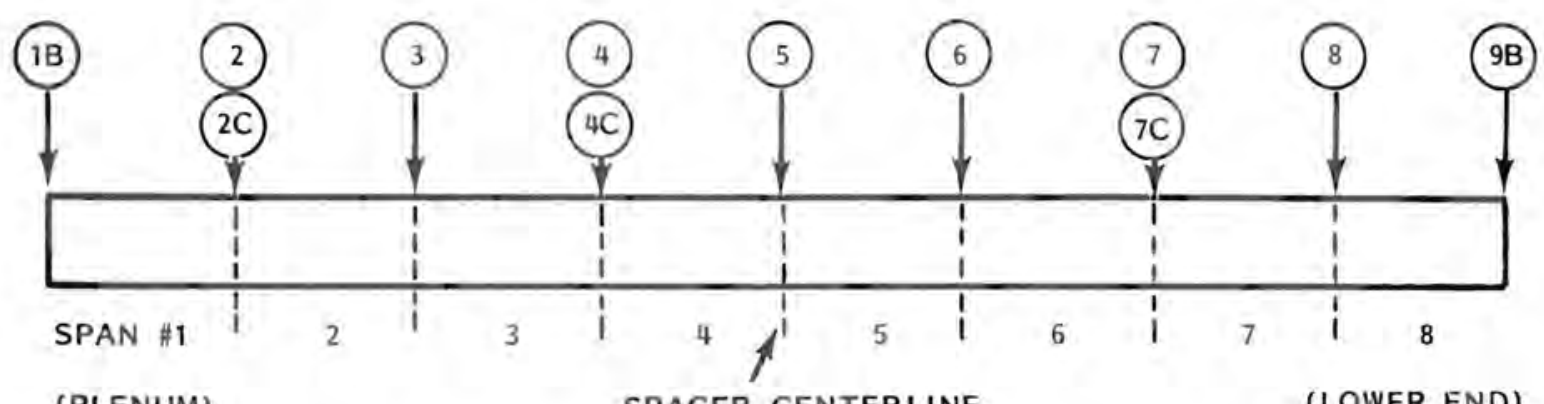

FIGURE 3. Location of Thermocouples on Rod 1D1(a)

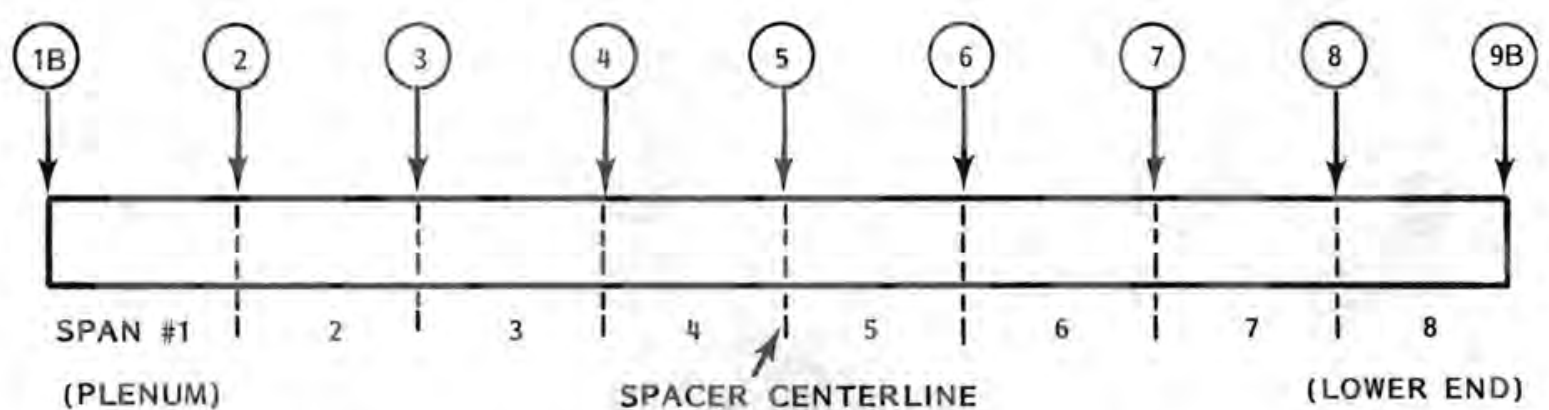

FIGURE 4. Location of Thermocouples on Rods $4 F 1$ and T3(a)

Prior to testing, each rod was pressurized with helium to $3.4 \mathrm{MPa}$ (500 psig at $30^{\circ} \mathrm{C}$ ), which is the approximate pressure in a spent fuel rod. (3) The pressure was monitored overnight to assure that there were no leaks. Pressure was measured by a sensor connected to the plenum by a capillary tube.

(a) TC numbers appended with letters A or B are located on the cladding or end caps. All other TCs are on the spacers. 
Each rod was individually tested while centered in a 5.1-cm (2-in.) diameter by $6-m(20-f t)$ long stainless steel pipe (the test can). A cap was welded on one end of the test can, and a blind flange with instrument fittings and an 0 -ring seal were attached to the other end. The end of the test rod containing the plenum was inserted into the test can first using a stainless steel rod with heat baffles (see Figure 1c). The test can was sealed, placed in the furnace as shown in Figure 5, and evacuated to an air pressure of $25.4 \mathrm{~cm} \mathrm{of} \mathrm{Hg}$ vacuum ( 9.8 psia).

Testing was done in a horizontal furnace (see Figure 5) that was $4.3 \mathrm{~m}$ $(14 \mathrm{ft})$ long with a door opening of $0.3 \times 0.5 \mathrm{~m}(1 \times 1.5 \mathrm{ft})$. The resistanceheating elements were located at $15-\mathrm{cm}(6-\mathrm{in}$.) intervals over $4 \mathrm{~m}$ (13 ft) of the furnace length. A brick wall was built in the furnace door opening so that the test can could extend $\sim 1.8(\sim 6 \mathrm{ft})$ outside the furnace during testing to decrease the operational temperature of the 0 -ring seal in the blind flange.

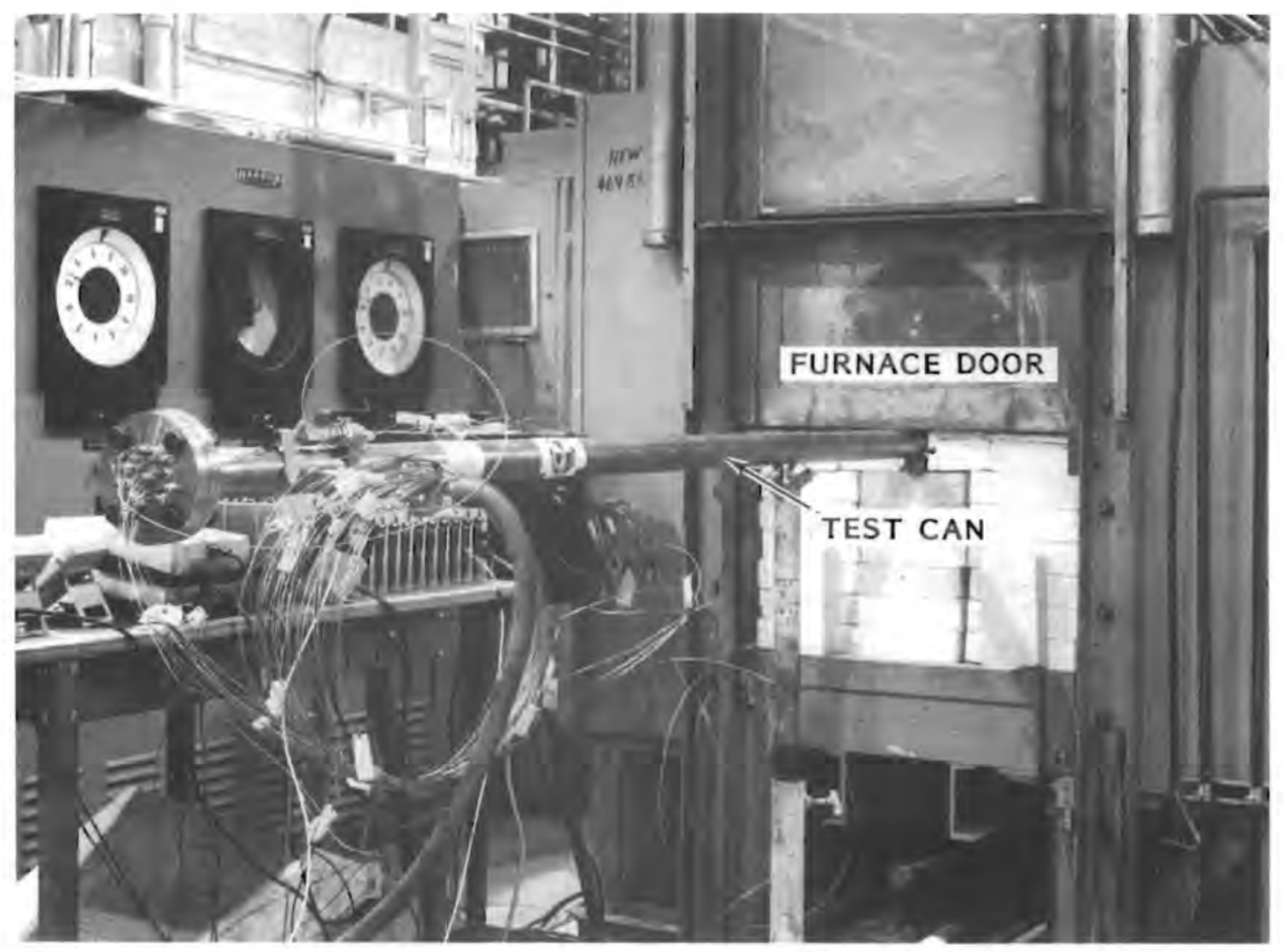

FIGURE 5. Arrangement of Test Equipment During Furnace Testing 
The furnace heating rate was controlled manualiy by setting and adjusting the level and duration of the electric current, and furnace temperatures were monitored by TCs that provided output to a strip chart recorder.

The data were taken electronically using a Fluke data logger(a) during the tests involving the dummy rod and rod 1D1. During testing of rod 1D1, the data logger failed. Data were subsequently taken using several voltmeters; the readings (in mVs) were converted to temperature (in ${ }^{\circ} \mathrm{C}$ ) and pressure (in $\mathrm{MPa}$ ).

(a) The Fluke data logger (Model 2240B) is a product of the Fluke Manufacturing Co., Tukwila, Washington. 


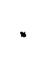




\section{TEST RESULTS}

Four tests were completed: one test was conducted using a dummy rod that contained a stainless steel rod instead of $\mathrm{UO}_{2}$ fuel and three tests were conducted with $3 \%$-enriched $\mathrm{UO}_{2}$ fuel rods. The three fuel rods were designated 1D1, 4F1, and T3. The dummy rod (first test) and rod 1D1 (second test) were heated at $\sim 56^{\circ} \mathrm{C} / \mathrm{h}$ and $\sim 53^{\circ} \mathrm{C} / \mathrm{h}$, respectively, which are near the maximum heating rate available from the furnace. Rod $4 \mathrm{~F} 1$ (third test) was heated at $\sim 10^{\circ} \mathrm{C} / \mathrm{h}$, and rod T3 (fourth test) was heated at $\sim 40^{\circ} \mathrm{C} / \mathrm{h}$. The results of the four tests are shown in Table 2.

The temperature and pressure histories for the test rods are shown in Figures 6 through 9. Because temperatures were partially manually controlled, the tests with the dummy rod and rod $1 D 1$ experienced some overshooting of the initial desired temperature of $300^{\circ} \mathrm{C}$ (see figure 6 ). The rods were quickly heated to the initial $300^{\circ} \mathrm{C}$ temperature to decrease the length of the experiment. The data indicate that $300^{\circ} \mathrm{C}$ was sufficiently below the temperature at which deformation began. The temperature along rod $1 D 1$ decreased by 200 to $300^{\circ} \mathrm{C}$ between the the last spacer (TC 8) and the bottom of the rod (TC 9B). This axial decrease was expected because of the heat loss through the furnace door and was the primary reason for inserting the plenum into the furnace first. The temperature over the remainder of the rod was relatively uniform $\left( \pm 20^{\circ} \mathrm{C}\right)$. The moment of failure was indicated by the rapid decrease in rod gas pressure (see Figures 6 through 9).

TABLE 2. Results of Furnace Tests

\begin{tabular}{|c|c|c|c|c|c|}
\hline Rod & $\begin{array}{c}\text { Heating } \\
\text { Rate, } \\
{ }^{\circ} \mathrm{C} / \mathrm{h} \\
\end{array}$ & $\begin{array}{c}\text { Peak } \\
\text { Pressure, } \\
\text { MPa (psig) } \\
\end{array}$ & $\begin{array}{c}\text { Failure } \\
\text { Pressure, } \\
\mathrm{MPa} \text { (psig) } \\
\end{array}$ & $\begin{array}{c}\text { Failure } \\
\text { Temperature, }{ }^{\circ} \mathrm{C} \\
\end{array}$ & $\begin{array}{c}\text { Average } \\
\text { Strain,(a) } \%\end{array}$ \\
\hline Dummy & 55.5 & $8.5(1232)$ & $3.0(435)$ & 710 & 10.2 \\
\hline $1 D 1$ & 52.9 & $7.6(1110)$ & $1.9(281)$ & 763 & 17.1 \\
\hline T3 & 39.5 & $7.6(1103)$ & $1.6(233)$ & 801 & 21.4 \\
\hline $4 \mathrm{~F} 1$ & 9.9 & $7.4(1072)$ & $1.0(150)$ & 800 & 36.4 \\
\hline
\end{tabular}

(a) Average of the diametral strain at the midspan of typical portions of the rod as measured by hand calipers. 

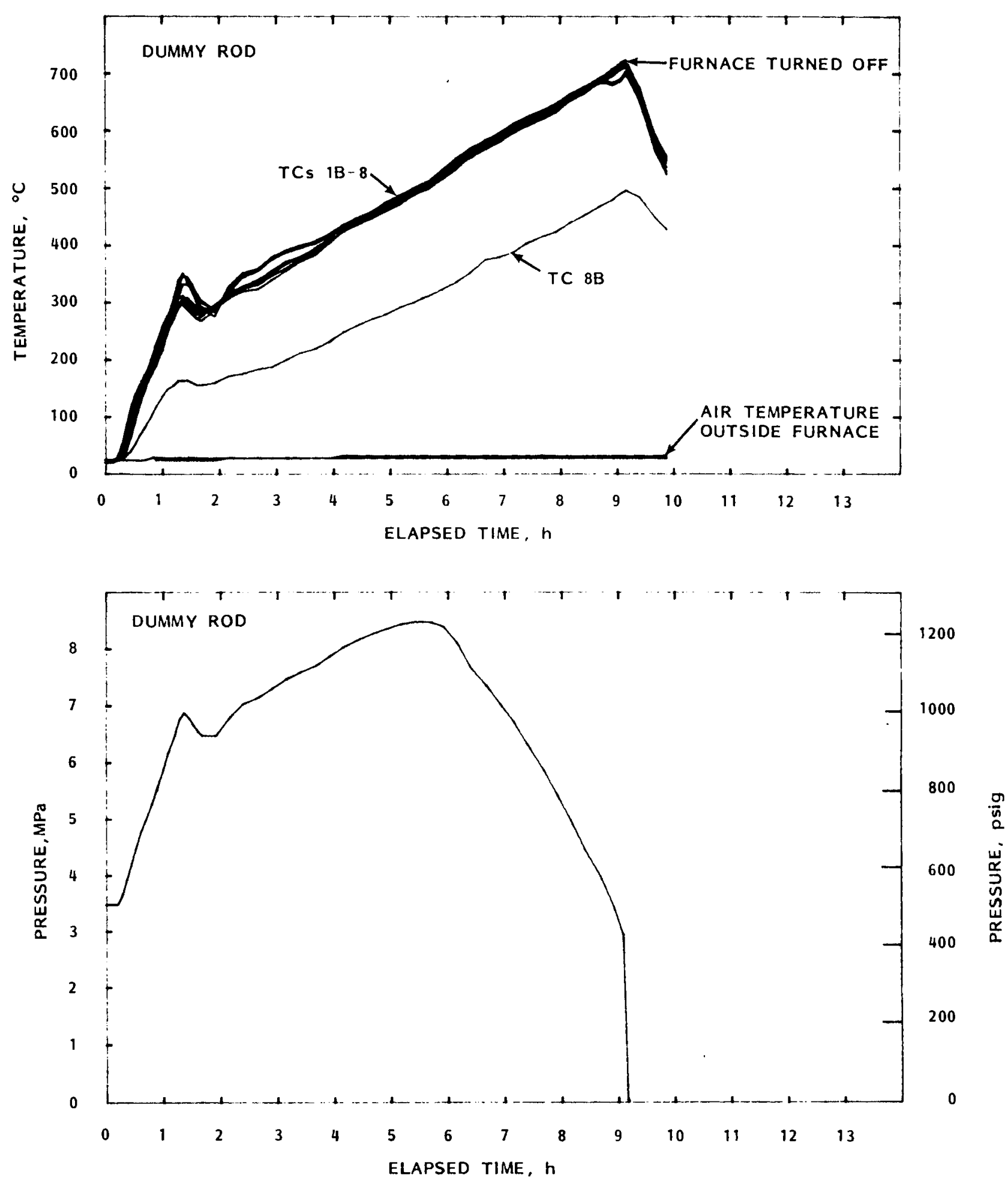

FIGURE 6. Temperature and Pressure Data for the Dummy Rod (tested at $\sim 56^{\circ} \mathrm{C} / \mathrm{h}$ ) 

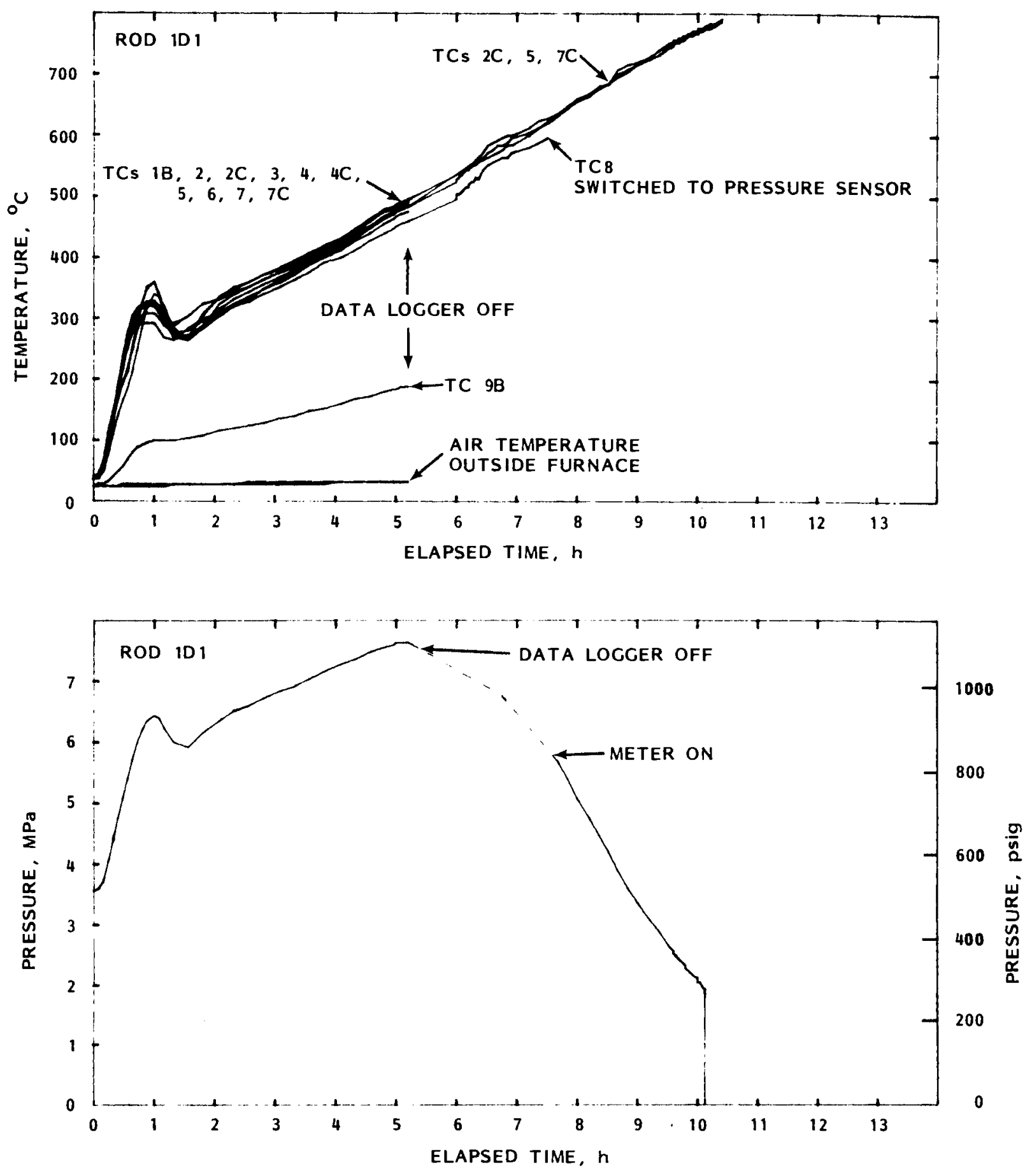

FIGURE 7. Temperature and Pressure Data for Rod $1 D 1$ (tested at $\sim 53^{\circ} \mathrm{C} / \mathrm{h}$ ) 

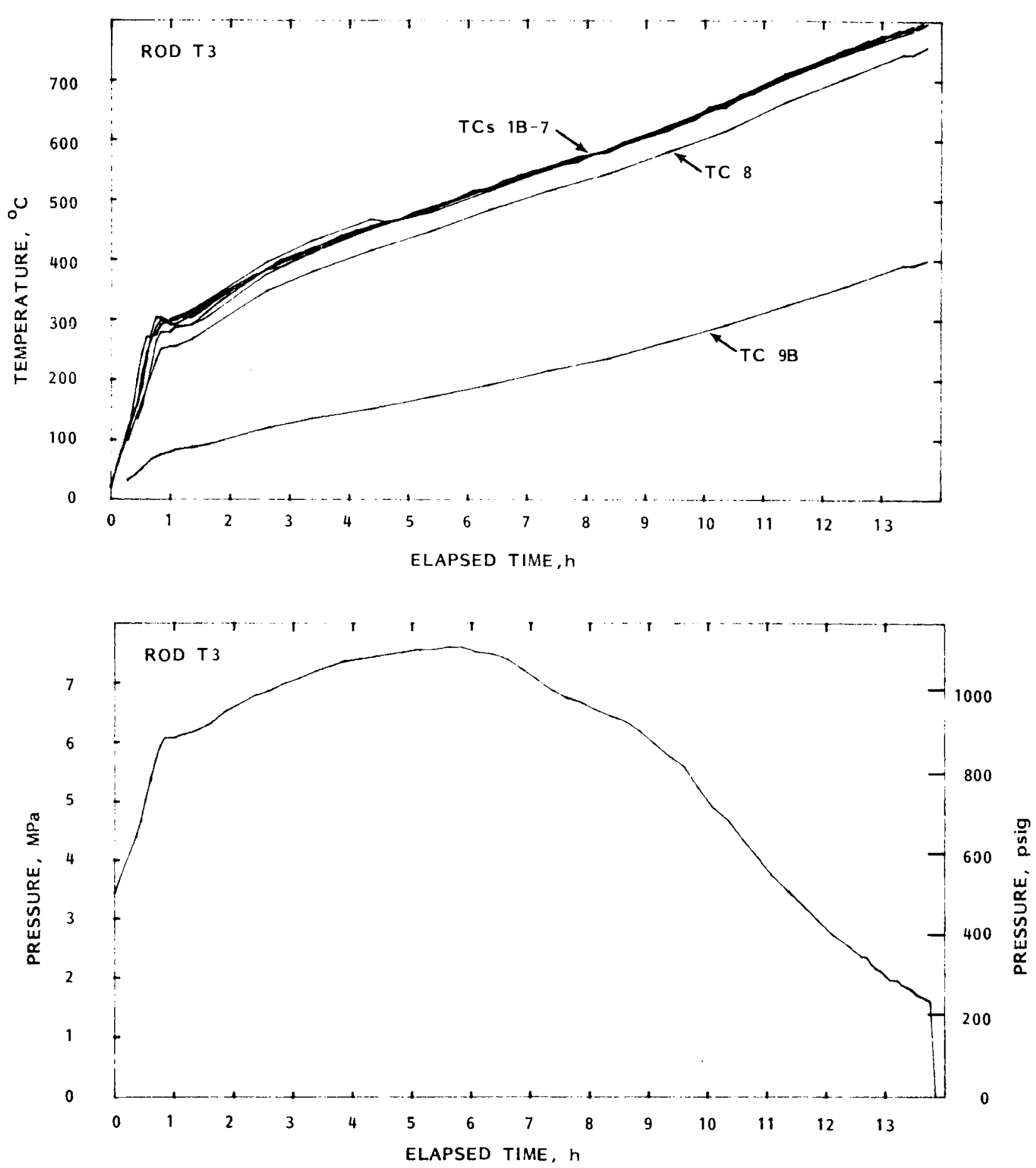

FIGURE 8. Temperature and Pressure Data for Rod $T 3$ (tested at $\sim 40^{\circ} \mathrm{C} / \mathrm{h}$ ) 

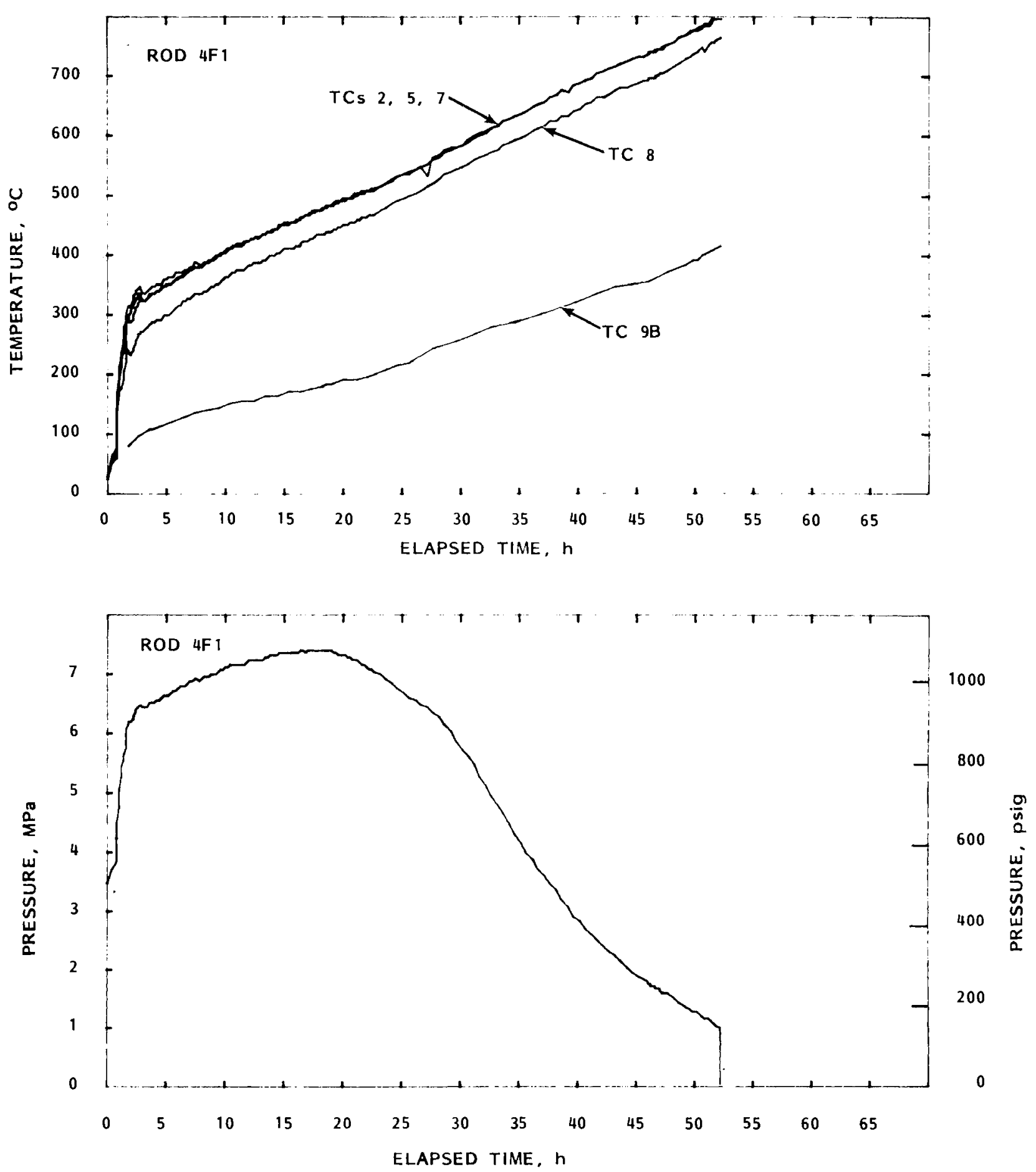

FIGURE 9. Temperature and Pressure Data for Rod $4 \mathrm{~F} 1$ (tested at $\sim 10^{\circ} \mathrm{C} / \mathrm{h}$ ) 
The general deformation characteristics of the test rods were similar. Each rod failed at a tiny $(\sim 150 \mu \mathrm{m})$ axial crack that formed at a localized region of the rod where the cladding diameter increased $\sim 100 \%$ compared with the typical diametral strains listed in Table 2. Enlargements of the failure sites and the general nature of the cracks are shown in Figures 10 through 12.

Although each failure occurred at a single site, the failures occurred at different axial locations. The dummy rod and rod 101 failed in span 7 while rods $4 F 1$ and $T 3$ failed in spans 2 and 4 , respectively. Because the cladding temperatures were very uniform along the rod (except for the short region near the furnace door), there was no correlation between the failure span and temperature or temperature history.

In addition to general ballooning, all of the test rods except the dummy rod sagged $\sim 0.75 \mathrm{~cm}(0.3 \mathrm{in.})$ at the middle of each span. The sag for rod $4 \mathrm{~F} 1$ is particularly evident in Figure 12. The dummy rod did not sag because the stainless steel rod provided support during heating. 


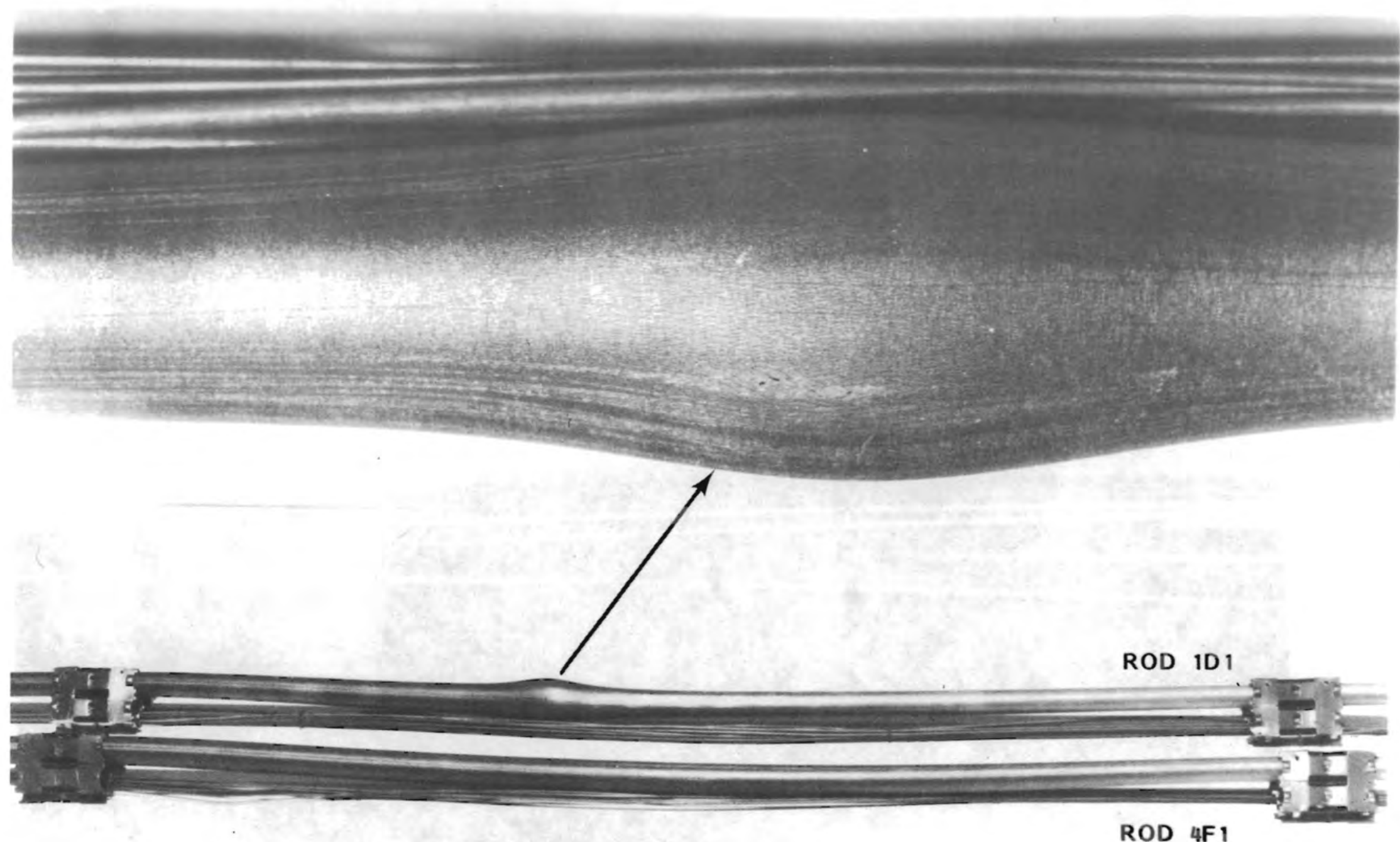

FIGURE 10. Rods $1 \mathrm{D} 1$ and $4 \mathrm{~F} 1$ After Testing at $\sim 53^{\circ} \mathrm{C} / \mathrm{h}$ and $\sim 10^{\circ} \mathrm{C} / \mathrm{h}$, Respectively, Compared with Enlargement (3.1X) of Failure Site in Rod 101 


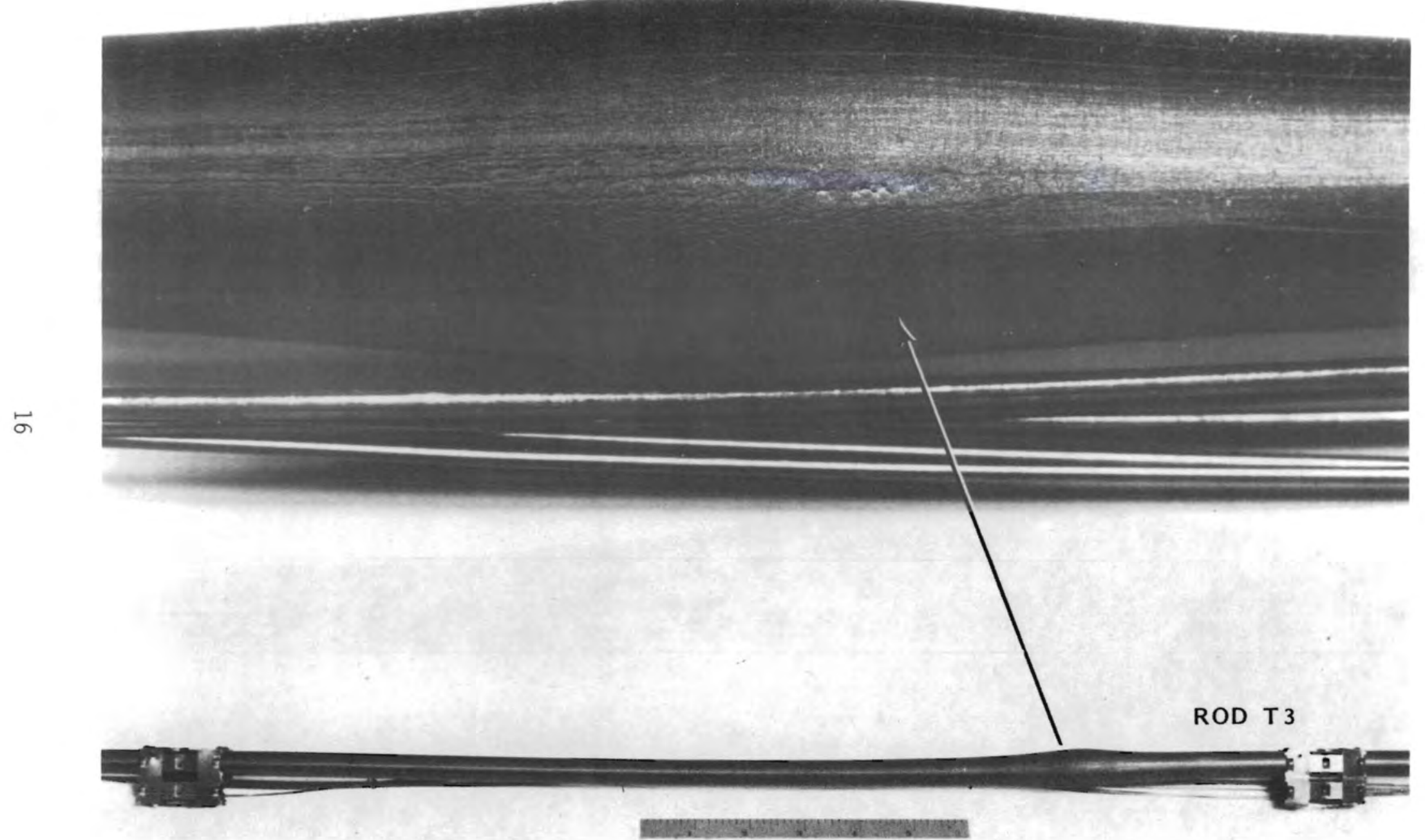

FIGURE 11. Rod T3 After Testing at $\sim 40^{\circ} \mathrm{C} / \mathrm{h}$ Compared with Enlargement (3.2X) of Failure Site 


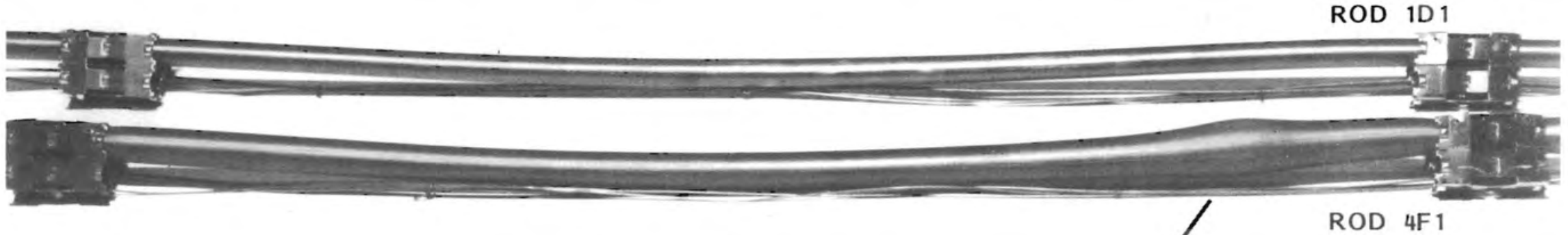

FIGURE 12. Rods $1 \mathrm{D} 1$ and $4 \mathrm{~F} 1$ After Testing at $\sim 53^{\circ} \mathrm{C} / \mathrm{h}$ and $\sim 10^{\circ} \mathrm{C} / \mathrm{h}$, Respectively, Compared with Enlargement (3.3X) of Failure Site in Rod $4 F 1$ 
-

,

-

.

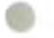




\section{METALLOGRAPHY}

Several specimens from rods 1D1, T3, and 4F1 were examined to determine cladding diameters and thicknesses for calculating cladding stresses; grain growth, hydriding, and cladding oxidation were also examined. Transverse sections of the cladding were taken at or near the failure site and from span 1 for all the rods. An additional section was taken from the cooler end (span 8) of rods $1 D 1$ and $4 F 1$ to determine the original cladding structure since that part of the rod never exceeded $\sim 500^{\circ} \mathrm{C}$ (see Figures 6 through 9).

Cladding diameters and thicknesses at several locations on rods 1D1, T3, and $4 \mathrm{~F} 1$ are compared in Figures 13 through 15, respectively. In general, ballooning was symmetrical; the cladding thickness was uniform; and the crosssectional area of the cladding was constant for typical portions of the tested rods. Most of the cladding at the axial location of the failure had a uniform thickness, except over limited portions of the circumference, where the cladding thinned (see points $C$ in Figures $13 a$ and 14a). The cladding perforation in rod 101 (see point $A$ in Figure 13a) occurred at the necked down region of the cladding in a typical ductile failure.

Each cladding specimen was etched(a) to determine the effects of heating rate and/or strain on grain size. Examples of the grain size and structure for rod $1 D 1$, which was heated at the fastest rate $\left(\sim 53^{\circ} \mathrm{C} / \mathrm{h}\right)$ for the $\mathrm{UO}_{2}$-fueled rods, are shown in Figure 16. (b) The cold-worked structure of the as-fabricated cladding (Figure 16c) changed to more equiaxed $~ 13-u m$ grains (Figure 16b) for the typical diametral strain shown in Figure 13b. The grain size increased to $19 \mu \mathrm{m}$ for a typical thickness (point B in Figure 13a) at the failure location, which represents a $200 \%$ increase over the original grain size $(6.3 \mu \mathrm{m})$.

(a) The etchant was 45 parts $\mathrm{HNO}_{3}$ and water plus 10 parts HF.

(b) The grain size was determined by counting the number of grains in each figure, measuring the total figure area, and converting this to an equiaxed grain size. 


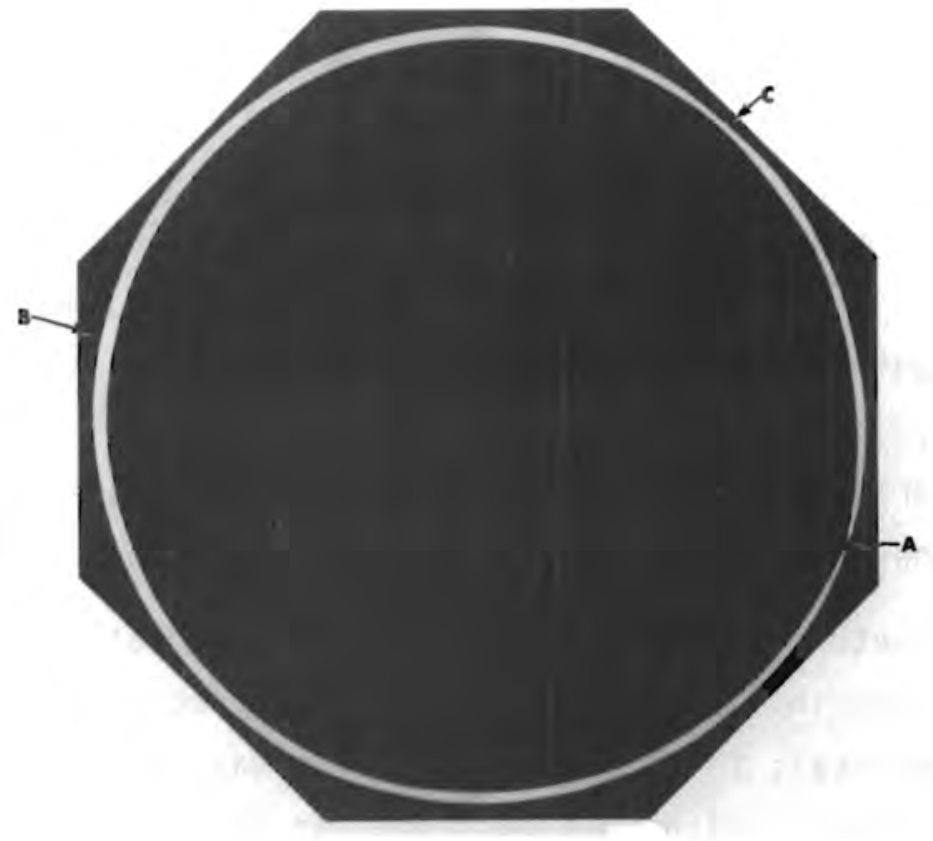

NEG. 4S980A-D

(a) FAILURE SITE

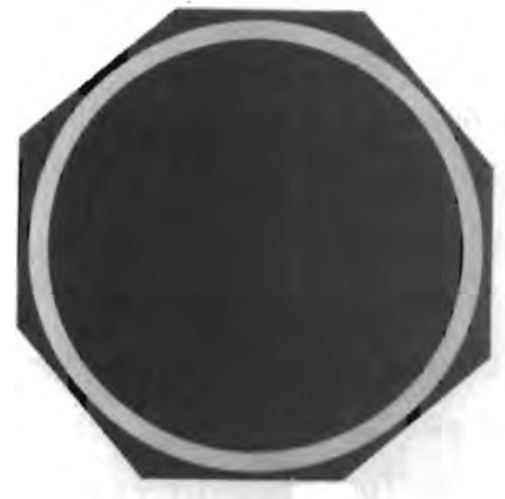

NEG. 4S979A, B

(b) TYPICAL DEFORMATION

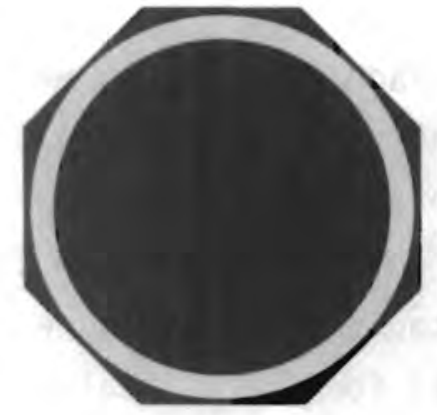

NEG. 4S978A

(c) UNDEFORMED CLADDING

FIGURE 13. Comparison of Cladding Diameters and Thicknesses at Several Locations on Rod 101 After Testing (4X) 


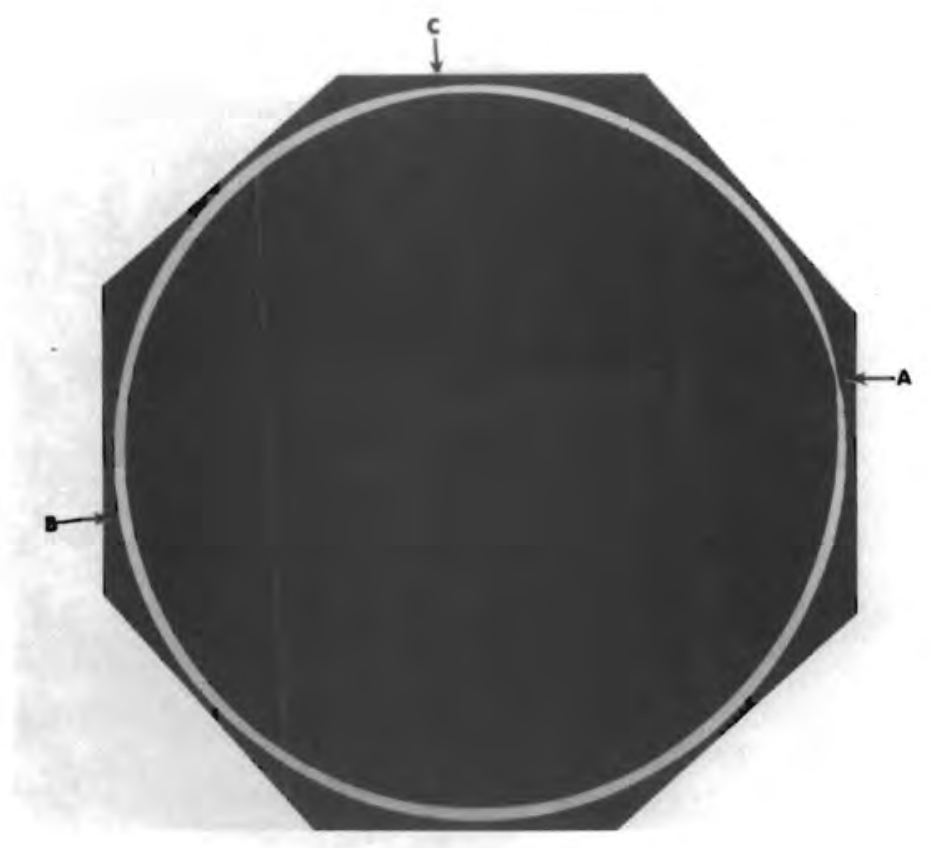

NEG. 4S977A-D

(a) FAILURE SITE

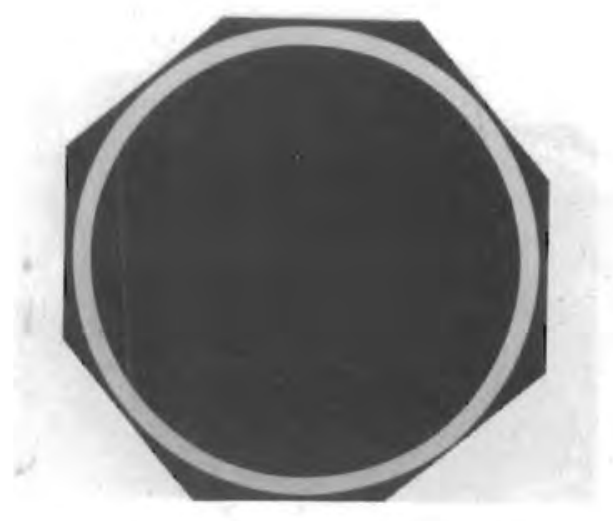

NEG, 4S976A, B

(b) TYPICAL DEFORMATION

FIGUPE 14. Comparison of Cladding Diameters and Thicknesses at Two Locations on Rod T3 After Testing (4X) 


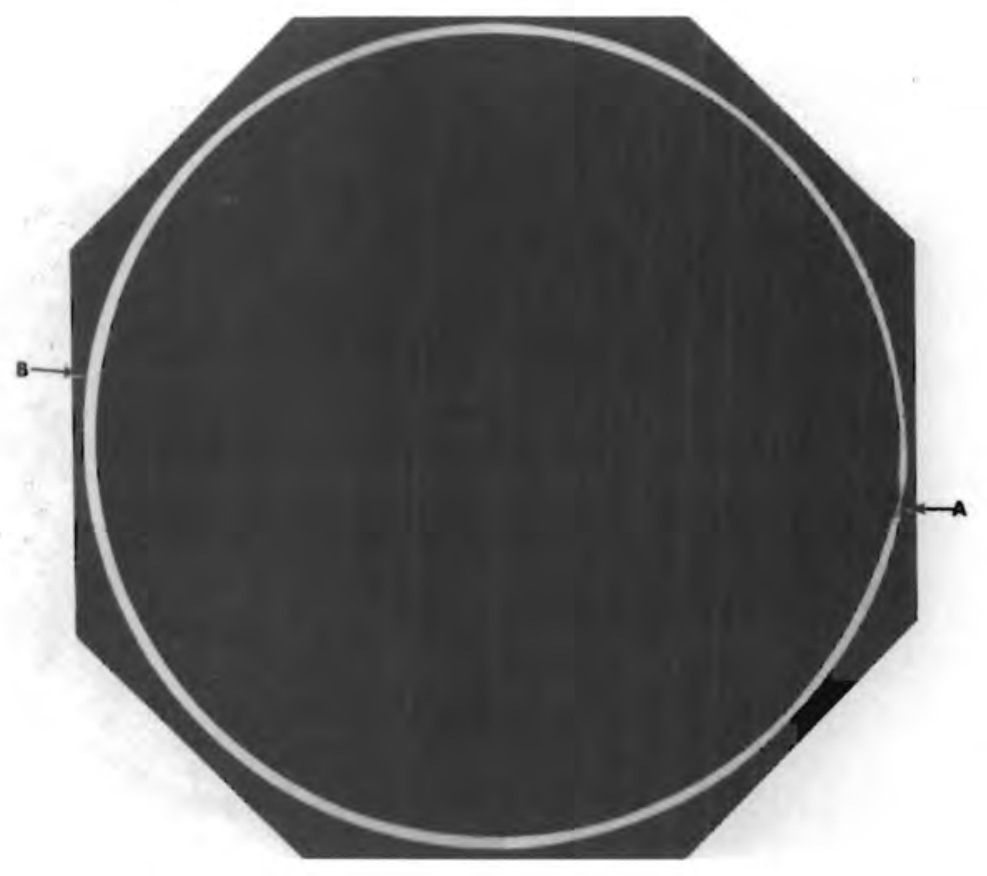

NEG. 4S983A-D

(a) FAILURE SITE

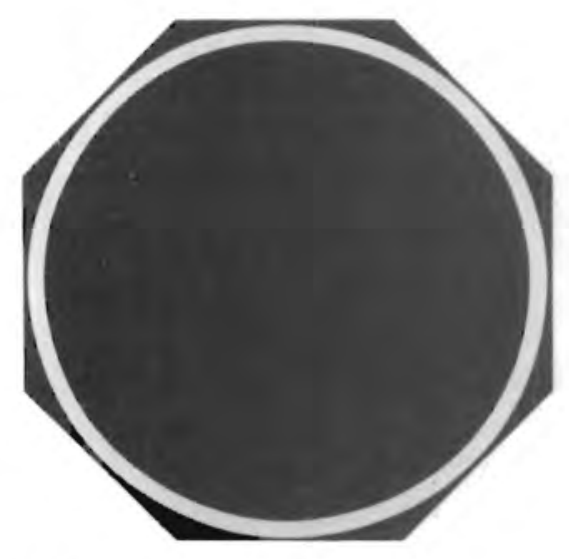

NEG. 4S982A, B

(b) TYPICAL DEFORMATION

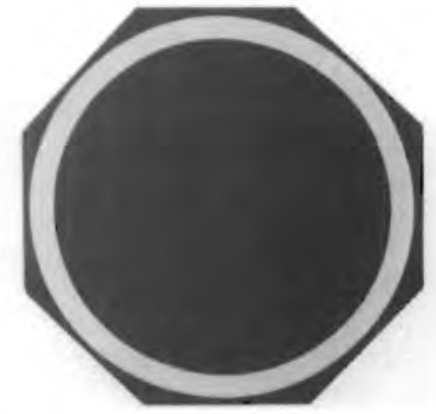

NEG. 4S981A

(c) UNDEFORMED CLADDING

FIGURE 15. Comparison of Cladding Diameters and Thicknesses at Several Locations on Rod 4F1 After Testing (4X) 


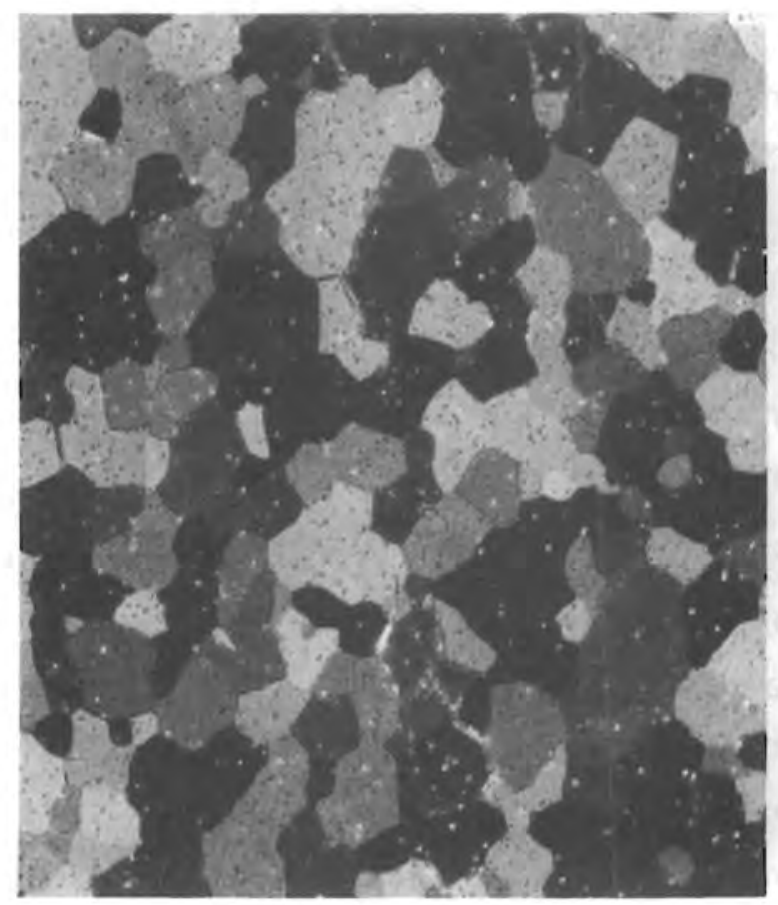

NEG. 4S983L

(a) FAILURE SITE STRUCTURE (NEAR POINT A IN FIGURE 13a)

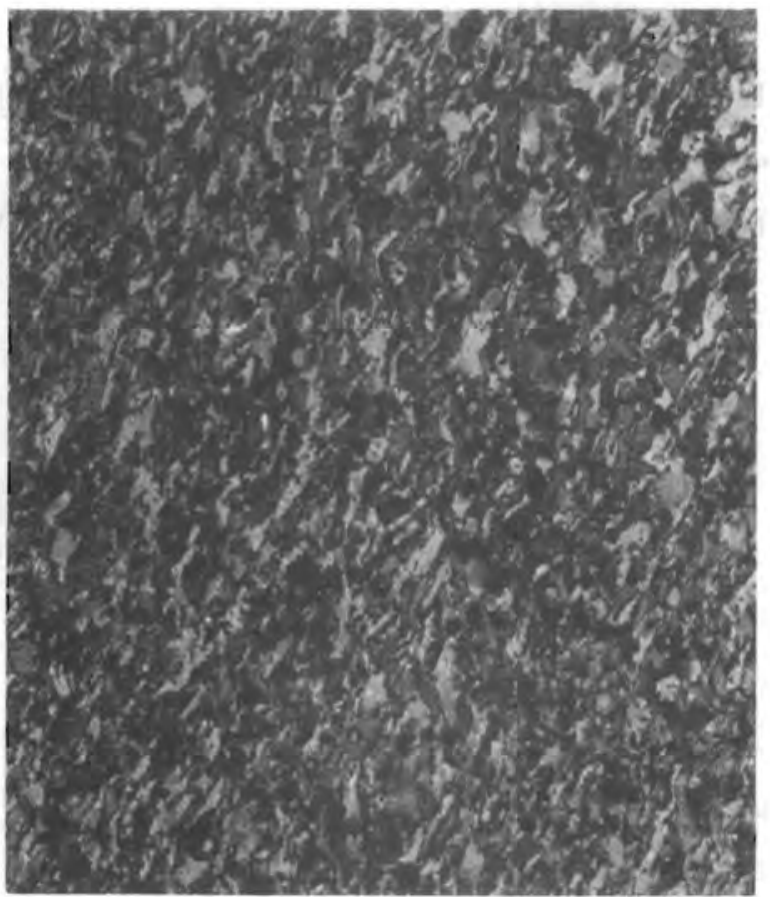

NEG. 4S981F

(c) ORIGINAL STRUCTURE (SEE FIGURE 13C)

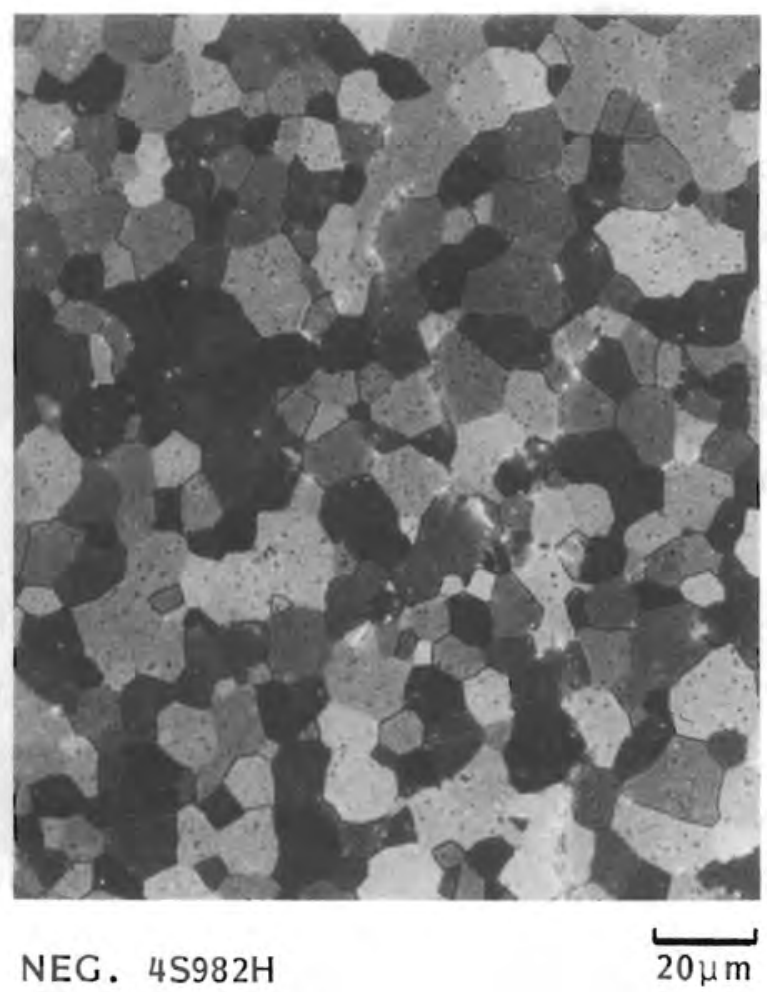

(b) TYPICAL STRUCTURE (SEE FIGURE 13b)

FIGURE 16. Transverse Sections Showing Grain Structure in Rod 1D1 (500X) 
Similar comparisons of the grain sizes for rods $T 3$ and $4 \mathrm{~F} 1$ are shown in Figures 17 and 18, respectively. The grain sizes and heating rates for all three test rods are presented in Table 3. Comparison of the data from the specimens of typically strained cladding (Figures 13b, 14b, and 15b) indicates that slower heating rates (i.e., more time at temperature) permitted greater grain growth. The trend in the grain sizes for typical thicknesses at the failure sites (point B in Figures 13 through 15) also indicates that slower heating rates permitted greater grain growth.

Mechanical deformation also appears to be a factor in grain growth because thinner cladding had more grain growth than thicker cladding in the same rod at the same axial location. Near the actual failure sites (point A in Figures 13 through 15), the cladding failure resulted in a necked down region that was associated with grains up to 25 times the original size of $6.3 \mu \mathrm{m}$ (see Figure 19). The necked region did not have the largest grains, possibly because there was secondary recrystallization as the grains experienced high stresses and strain rates prior to failure. The largest grains were always associated with cladding that had thinned more than average for that location. The large grain size at the failure tip (shown in Figure 19a) gradually gives way to a region of mixed grain sizes. The typical grain size for the cladding below point $B$ in Figure $13 \mathrm{a}$ is also shown in Figure 19b. For this thicker cladding, the grain size is substantially smaller, even though the cladding was at or near the same temperature. Thus, changes in grain size apparently resulted from strain in the cladding as well as differences in the time at temperature.

The etched cladding specimens were also examined to determine if the tests affected the amount or orientation of the original hydride platelets. During the test, the hydride platelets increased in size but decreased in number as exhibited by longer hydrides (shown in Figure 20). The hydrides were not visibly affected by strain in the cladding because there was little difference between the hydride structure for maximum and typical cladding deformation. The original hydrides for rod 101 were oriented primarily circumferentially as indicated in Figure 20c. Only a slight increase was observed in the amount of radially oriented platelets (see Figures $20 \mathrm{a}$ and $20 \mathrm{~b}$ ). Thus, the total amount 


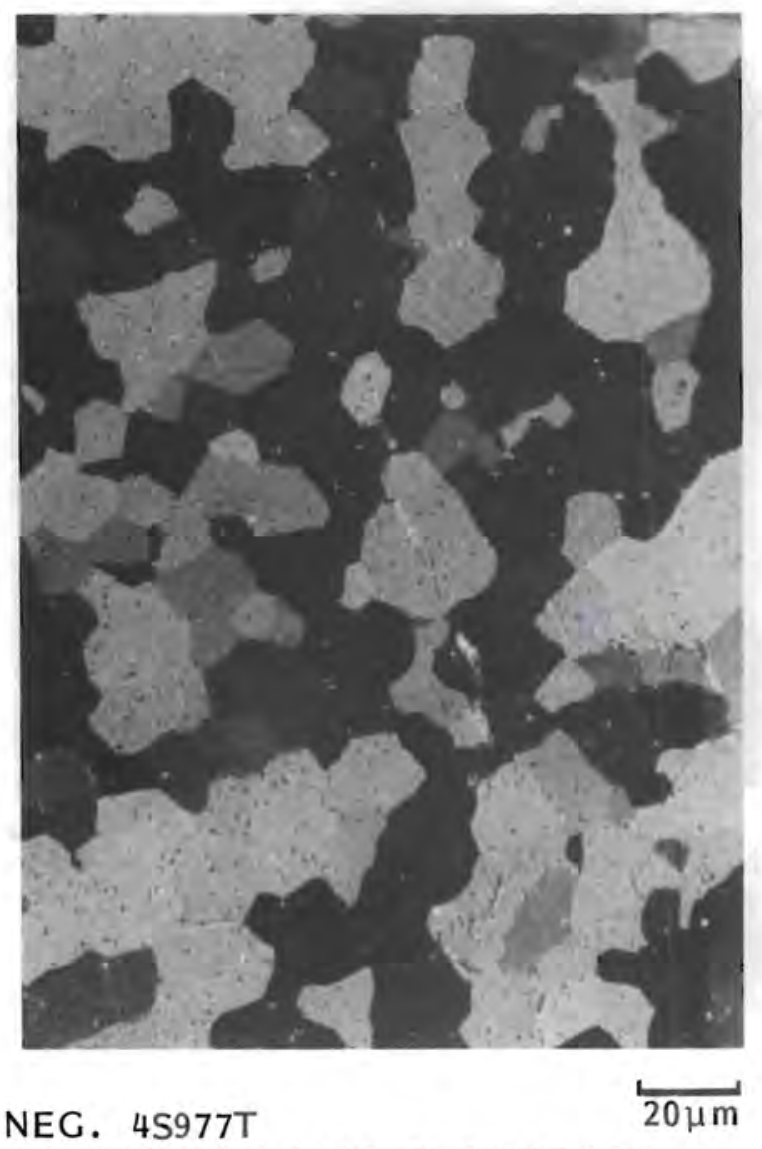

(a) FAILURE SITE STRUCTURE
(NEAR POINT A IN FIGURE 14a)

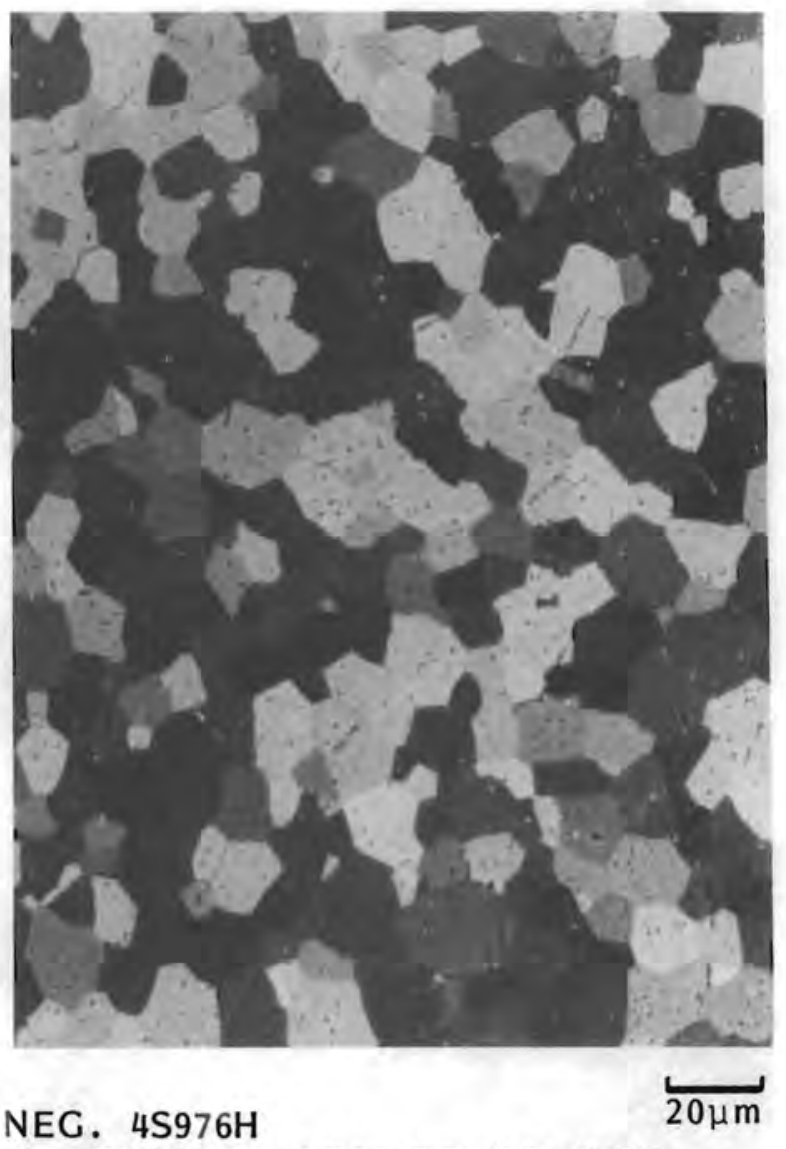

(b) TYPICAL STRUCTURE (SEE FIGURE 14b)

FIGURE 17. Transverse Sections Showing Grain Structure in Rod T3 (500X)

and orientation of the hydriding appear to be relatively unaffected by these slow heating rates, and the actual failure does not appear to be promoted by any changes in hydride structure.

Although the grain structure of the Zircaloy cladding was related to cladding failure, oxidation of the outside surface of the cladding was benign. Samples of the oxide that formed on the cladding surface near the furnace door and at the failure sites are shown in Figure 21. The oxide layer was from 4 to $10 \mu \mathrm{m}$ thick and was periodically cracked along the circumference. The most notable difference between the rods with different heating rates was that greater diametral strain resulted in larger circumferential gaps in the oxide layer. 


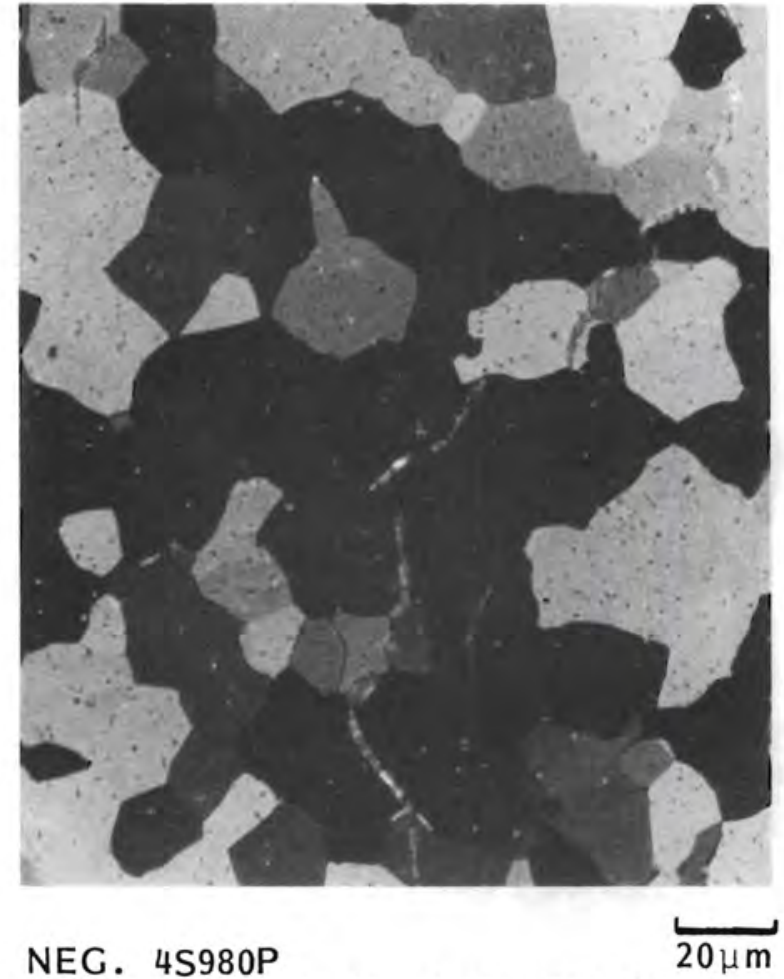

(a) FAILURE SITE STRUCTURE (NEAR POINT A IN FIGURE 15a)

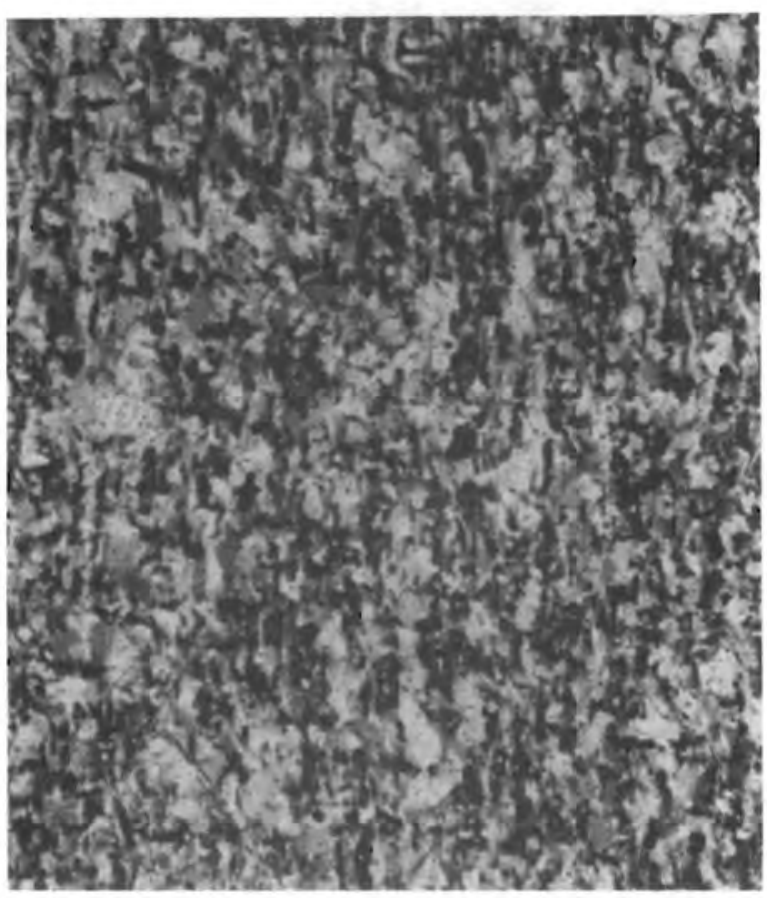

NEG. 4 S978C

(c) ORIGINAL STRUCTURE (SEE FIGURE 15C)

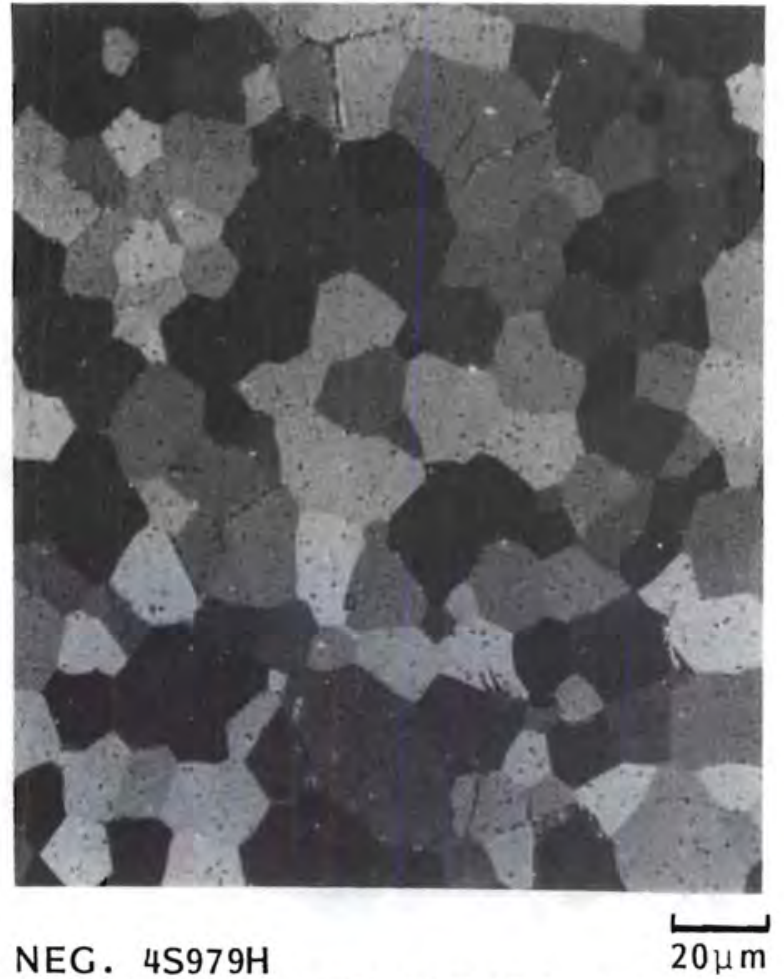

(b) TYPICAL STRUCTURE (SEE FIGURE 15b)

FIGURE 18. Transverse Sections Showing Grain Structure in Rod 4F1 (500X) 
TABLE 3. Comparison of Thermal and Mechanical Effects on Grain Size

\begin{tabular}{|c|c|c|c|c|c|}
\hline Location & $\begin{array}{l}\text { Rod } \\
\text { Number } \\
\end{array}$ & $\begin{array}{c}\text { Heating Rate, } \\
{ }^{\circ} \mathrm{C} / \mathrm{h} \\
\end{array}$ & $\begin{array}{c}\text { Grain Size, } \\
\mu \mathrm{m}\end{array}$ & $\begin{array}{l}\text { Stress, (a) } \\
\mathrm{MPa}(\mathrm{psi})\end{array}$ & $\begin{array}{c}\text { Strain, (b) } \\
\% \Delta t / t \\
\end{array}$ \\
\hline $\begin{array}{l}\text { Typical } \\
\text { (span 1) }\end{array}$ & $\begin{array}{l}4 \mathrm{~F} 1 \\
\mathrm{~T} 3 \\
1 \mathrm{D} 1\end{array}$ & $\begin{array}{r}9.9 \\
39.9 \\
52.9\end{array}$ & $\begin{array}{l}18 \\
15 \\
13\end{array}$ & $\begin{array}{ll}14.9 & (2,154) \\
19.5 & (2,831) \\
20.9 & (3,038)\end{array}$ & $\begin{array}{l}-27 \\
-23 \\
-17\end{array}$ \\
\hline $\begin{array}{l}\text { Failure } \\
\text { Point B }\end{array}$ & $\begin{array}{l}4 \mathrm{~F} 1 \\
\mathrm{~T} 3 \\
1 \mathrm{D} 1\end{array}$ & $\begin{array}{r}9.9 \\
39.9 \\
52.9\end{array}$ & $\begin{array}{l}27 \\
23 \\
19\end{array}$ & $\begin{array}{ll}39.1 & (5,672) \\
46.8 & (6,780) \\
49.3 & (7,143)\end{array}$ & $\begin{array}{l}-55 \\
-48 \\
-38\end{array}$ \\
\hline $\begin{array}{l}\text { Failure } \\
\text { Point A }\end{array}$ & $\begin{array}{l}4 \mathrm{~F} 1 \\
\mathrm{~T} 3 \\
1 \mathrm{D} 1\end{array}$ & $\begin{array}{r}9.9 \\
39.9 \\
52.9\end{array}$ & $\begin{array}{l}38 \\
28 \\
\text { NA (c) }\end{array}$ & $\begin{array}{c}183(26,540) \\
245(35,560) \\
\text { NA }(c)\end{array}$ & $\begin{array}{l}-90 \\
-90 \\
\text { NA }(c)\end{array}$ \\
\hline
\end{tabular}

\footnotetext{
(a) Hoop stress at failure was determined using known failure pressure and measured cladding diameters and average thicknesses.

(b) Percentage change in original wall thickness.

(c) Grain size and stress are not applicable (NA) for the actual failure site.
} 


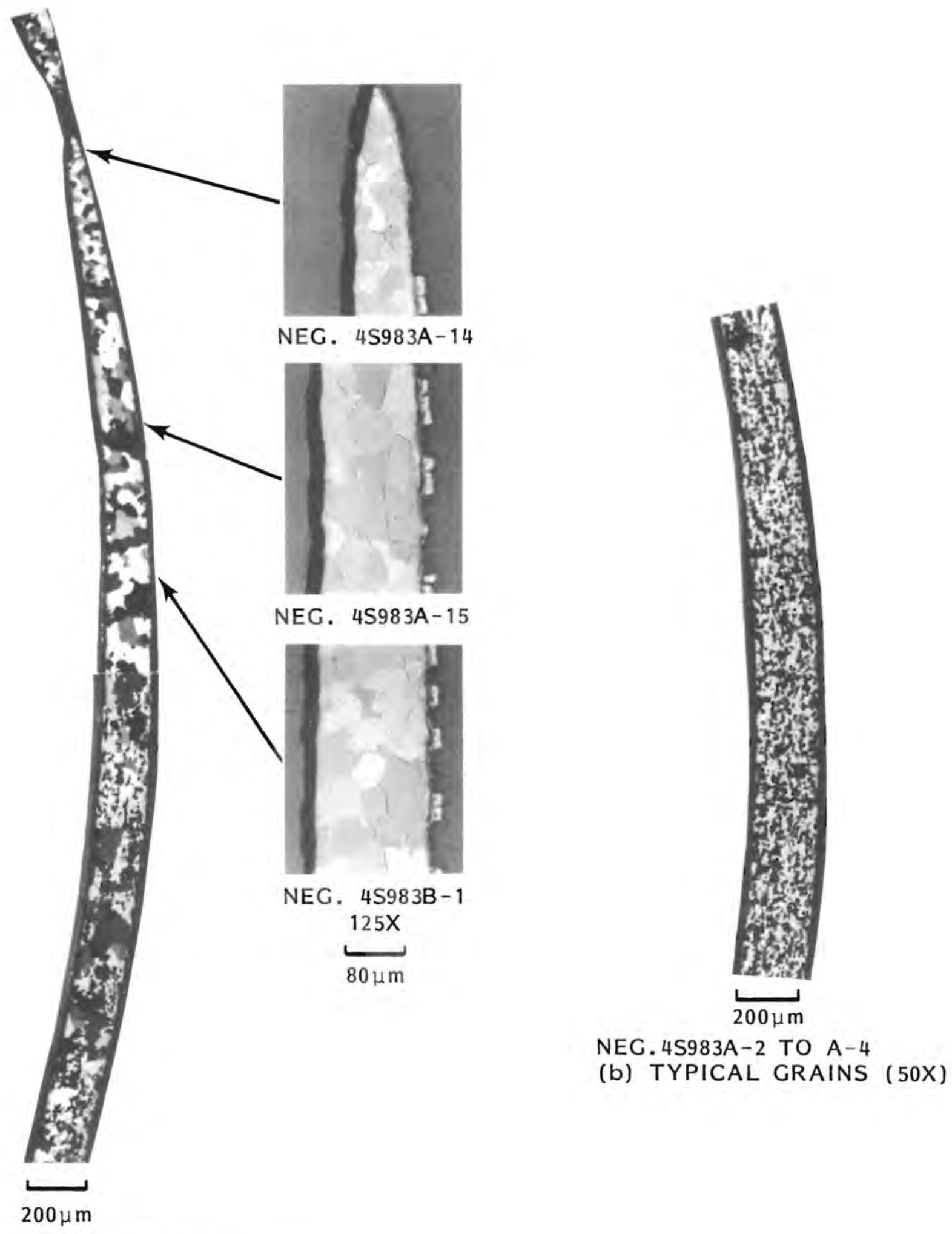

NEG. 4S983V TO A-1

(a) LARGE GRAINS (50X)

FIGURE 19. Variation in Grain Size for Different Cladding Thicknesses in Rod 101 


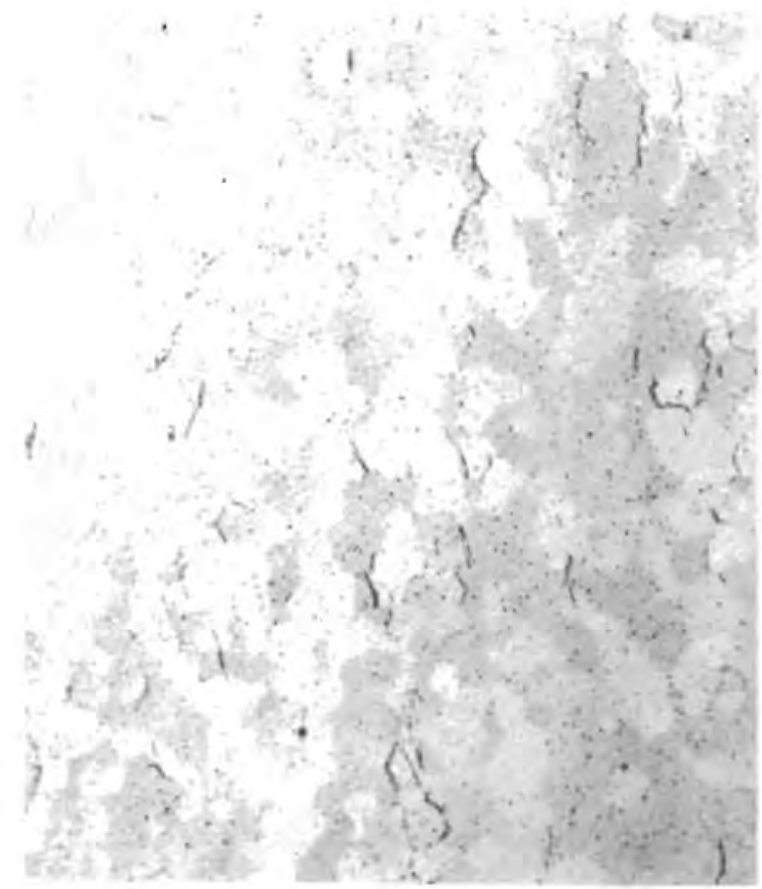

NEG. 4S983I

(a) NEAR FAILURE SITE (SEE $40 \mu \mathrm{m}$ POINT A IN FIGURE 13a)

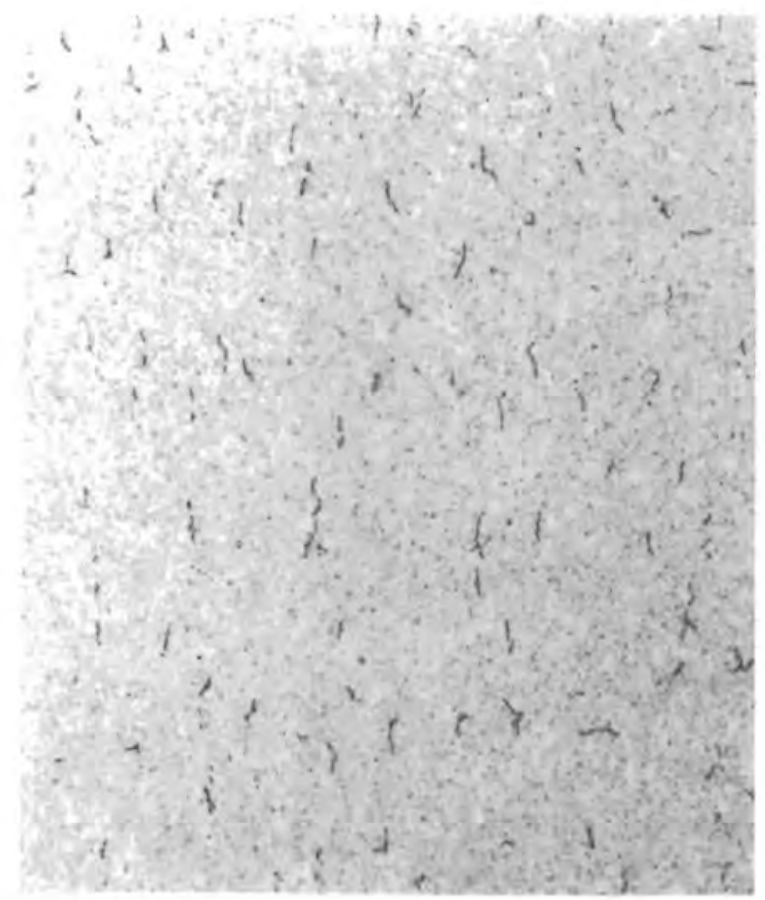

NEG. 4S981D

(c) ORIGINAL HYDRIDING (SEE $40 \mu \mathrm{m}$ FIGURE 13c)

FIGURE 20. Transverse Sections Showing Hydride Changes in Rod 1D1 (250X)

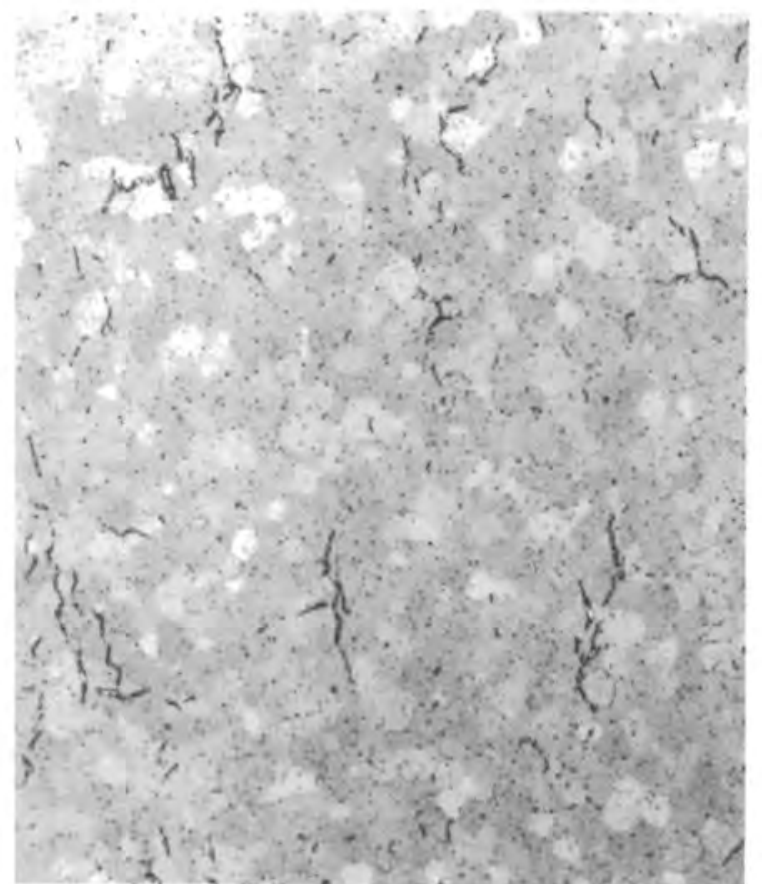

NEG. 4S982E

(b) TYPICAL CLADDING (SEE $40 \mu \mathrm{m}$ FIGURE 13b) 


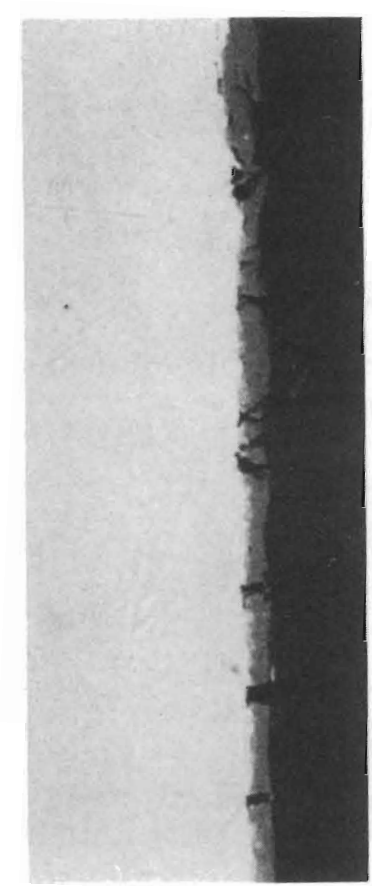

NEG. 4S982D

ROD ID 1

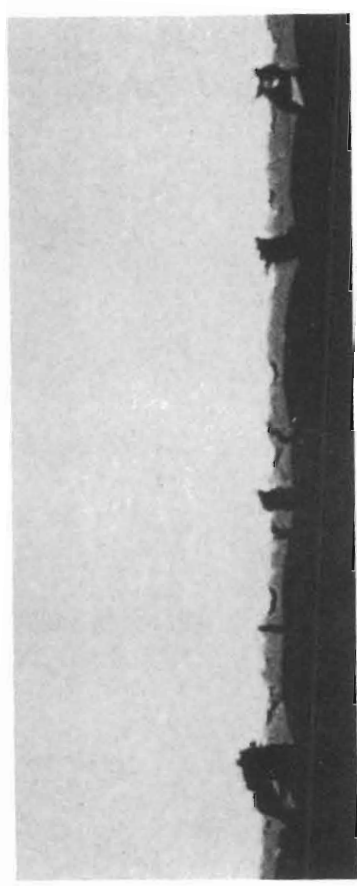

NEG , $4 S 9760$

ROD T 3

(a) TYPICAL (500X)

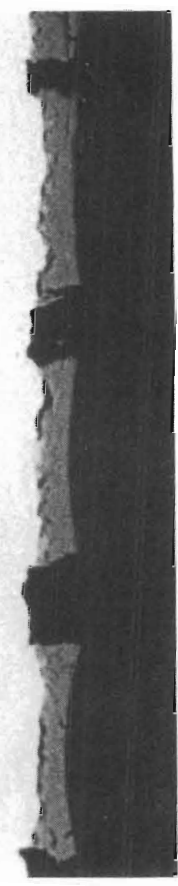

NEG. 4S9790

ROD $4 \mathrm{~F} 1$

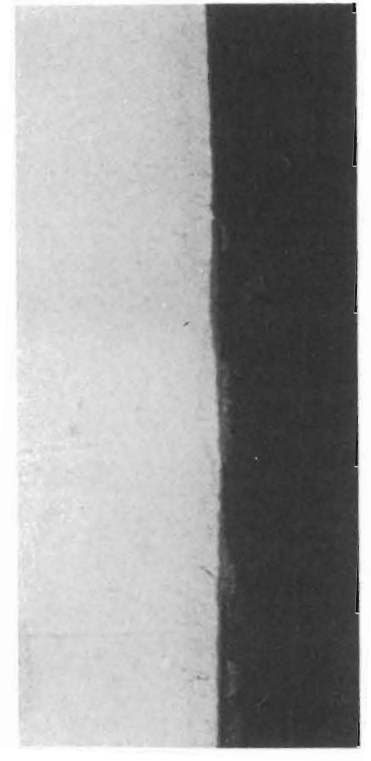

IVEL. 4S981B

ROD 1D 1

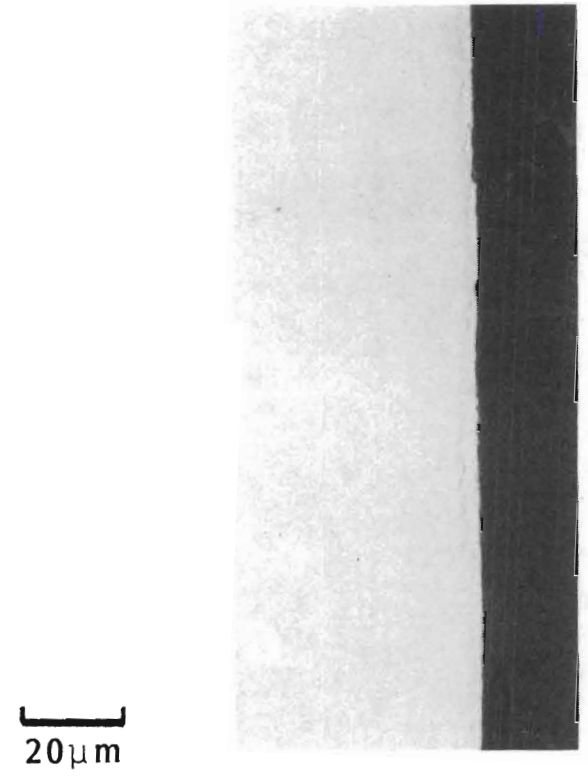

NEG. 4S978B

ROD 4F 1

(b) COOLER END (SPAN 8) (500X)

FIGURE 21. Cladding Oxidation at Typical Locations ( $800^{\circ} \mathrm{C}$ maximum)

Compared with Cladding Exposed to Temperatures $<500^{\circ} \mathrm{C}$ (500X) 


\section{DISCUSSION}

Pressure and temperature data for these tests on fu11-1ength PWR fuel rods indicate failure pressures lower than those for the faster heating rates typical of LOCA tests. Failure pressures and temperatures for fast heating rates $(5)$ are compared with the results from these tests in Figure 22 . Although the failure pressure decreased rapidly with increasing failure temperature for the slow heating rates, the absolute values are $\sim 0.7 \mathrm{MPa}$ ( 100 psi) lower than those for the faster heating rates. This result is not unexpected because longer times at elevated temperatures permit significant cladding creep, which increases the void volume and decreases gas pressures prior to failure. The cladding stresses at failure should alsa be lower for slower heating rates at a specific failure temperature.

Cladding stresses were calculated for each specimen using the known failure pressure, the measured cladding diameters, and average wall thicknesses measured at the failure location (see Table 3 ). The calculated stresses are plotted in Figure 23 along with failure data for irradiated cladding exposed to fast heating rates. (6) The solid curve in the figure is for unirradiated tube tests conducted at the Oak Ridge National Laboratory (ORNL). (6) The average cladding stresses at the failure location were lower than those for much faster heating rates.

The most significant difference between the slow and fast heating rates is the nature of the cladding failure. Slow heating rates permit enough creep to limit the cracks to very small dimensions (up to $150 \mu \mathrm{m}$ ). The small cracks formed in the furnace tests may be compared with the failure exhibited for rod $5 C$ from the NRU LOCA tests (Figure 24). (4) The Zircaloy cladding for the furnace tests and the NRU LOCA tests came from the same lot.

The smaller cracks that form during slow heatups can prevent the fuel loss that can result from faster heating rates (see Figure 25). (1) 0xidation of $\mathrm{UO}_{2}$ to $\mathrm{U}_{3} \mathrm{O}_{8}$ at $\sim 800^{\circ} \mathrm{C}$ would cause fuel swelling, particularly if the cask seal were to fail and allow unlimited air. The volume consumed by the fuel as it changed from $\mathrm{UO}_{2}$ to $\mathrm{U}_{3} \mathrm{O}_{8}$ would be accommodated by the significant increase in rod void volume. Additional fuel swelling could result from the formation of powder 


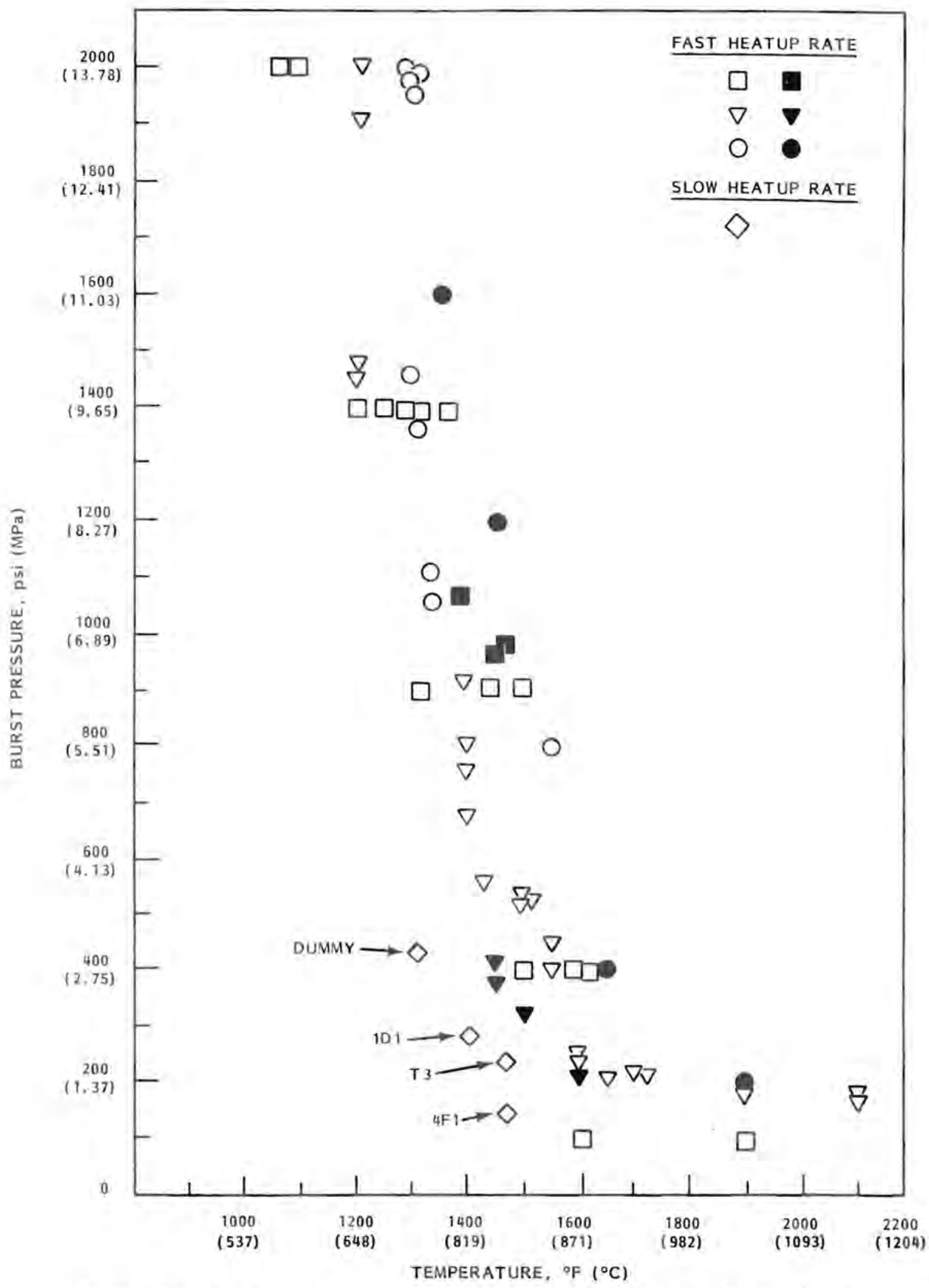

FIGURE 22. Failure Pressures and Temperatures for Fast(5) and Slow Heating Rates 


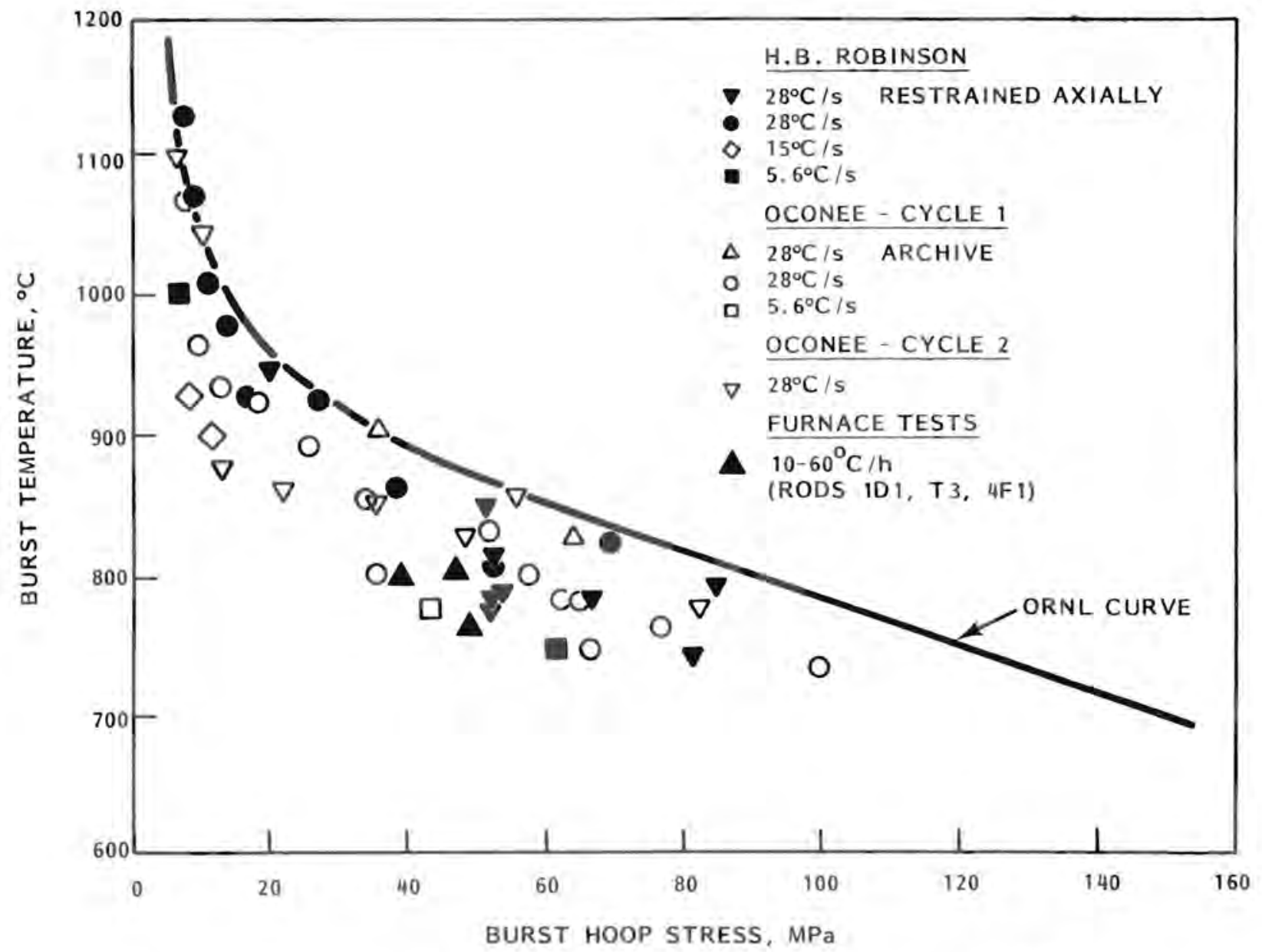

FIGURE 23. Failure Temperatures and Stresses for Fast (6) and Slow Heating Rates

$\mathrm{U}_{3} \mathrm{O}_{8}$, which has a lower effective density than solid $\mathrm{U}_{3} \mathrm{O}_{8}$. However, stresses would probably be prevented from becoming high enough to enlarge the crack. The large increase in void volume can be readily seen by comparing the diametral strain along rod $5 \mathrm{C}$ from the LOCA tests (4) with those of rods $1 D 1, T 3$, and 4F1 (Figure 26). Thus, a substantial barrier to the loss of solid radioactive material would still be maintained in slowly heated rods, which would reduce and facilitate the decontamination required after the overheating of a cask.

The furnace tests discussed in this report were run for individual fuel rods; and although the NRU fuel rods were tested in a $6 \times 6$ bundle (with the corner pins removed), the views of the NRU rod in Figure 24 indicate that adjacent fuel rods will be constrained if ballooning is significant. Ballooning was significant over the entire length of the rods tested at heating rates 


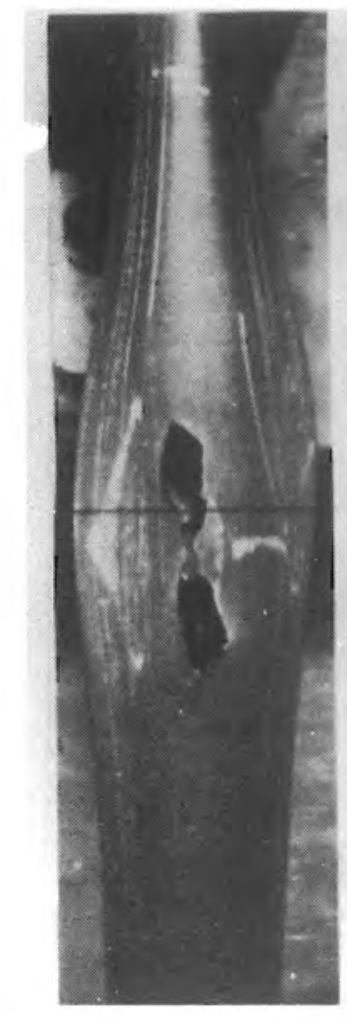

Rupture

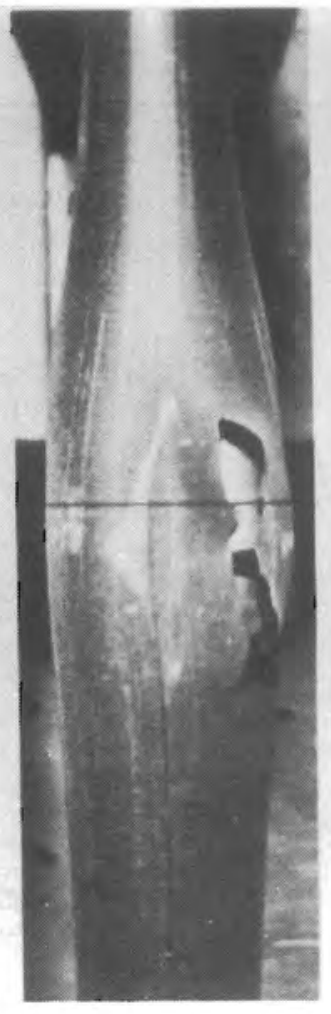

$0^{\circ}$

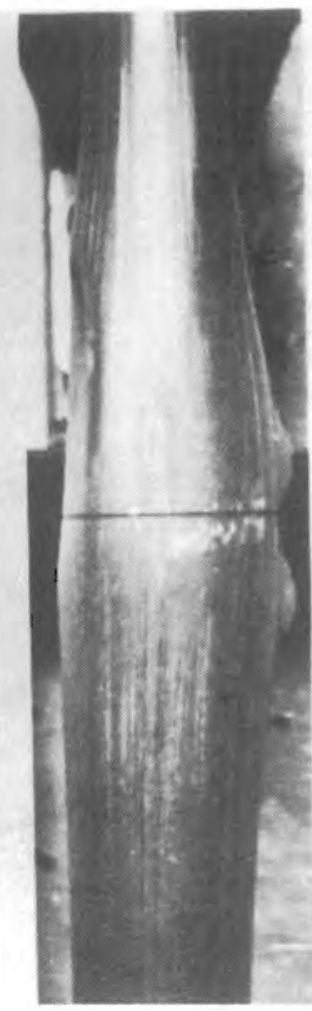

$90^{\circ}$

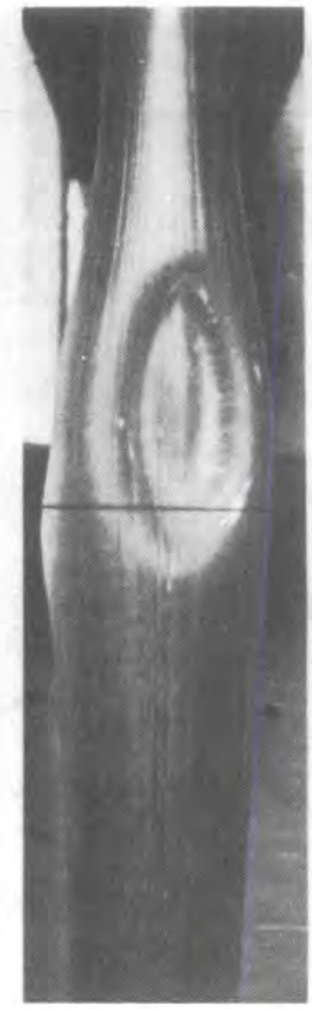

$180^{\circ}$

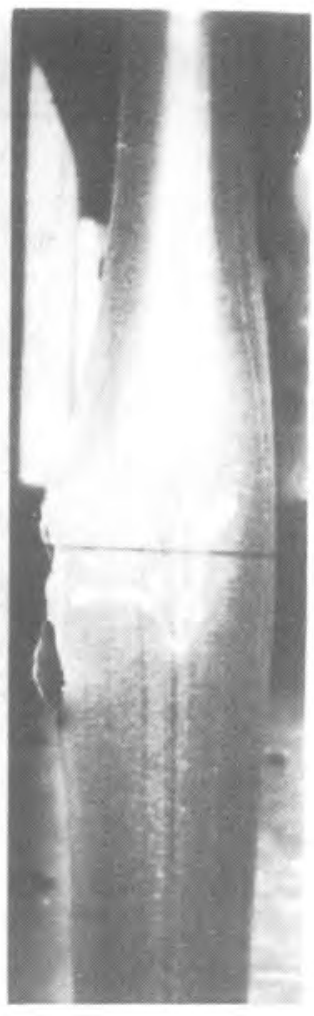

$270^{\circ}$

FIGURE 24. Rod $5 \mathrm{C}$ from the MT-3 Experiment in the NRU
Loss-of-Coolant Tests

$<60^{\circ} \mathrm{C} / \mathrm{h}$. Thus, rod-to-rod constraint would be expected and might affect the failure pressures. The significance of rod-to-rod constraint on failure conditions is not known. 


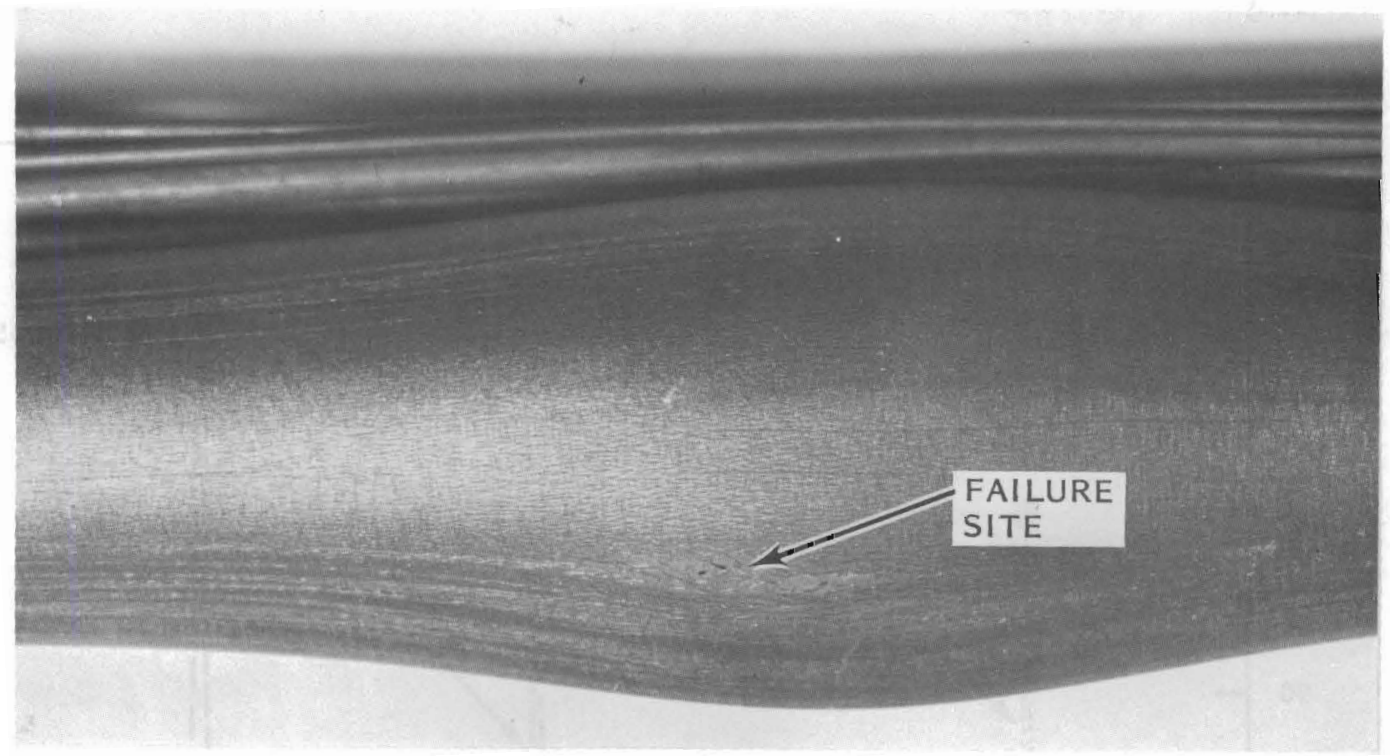

(a) ROD ID1

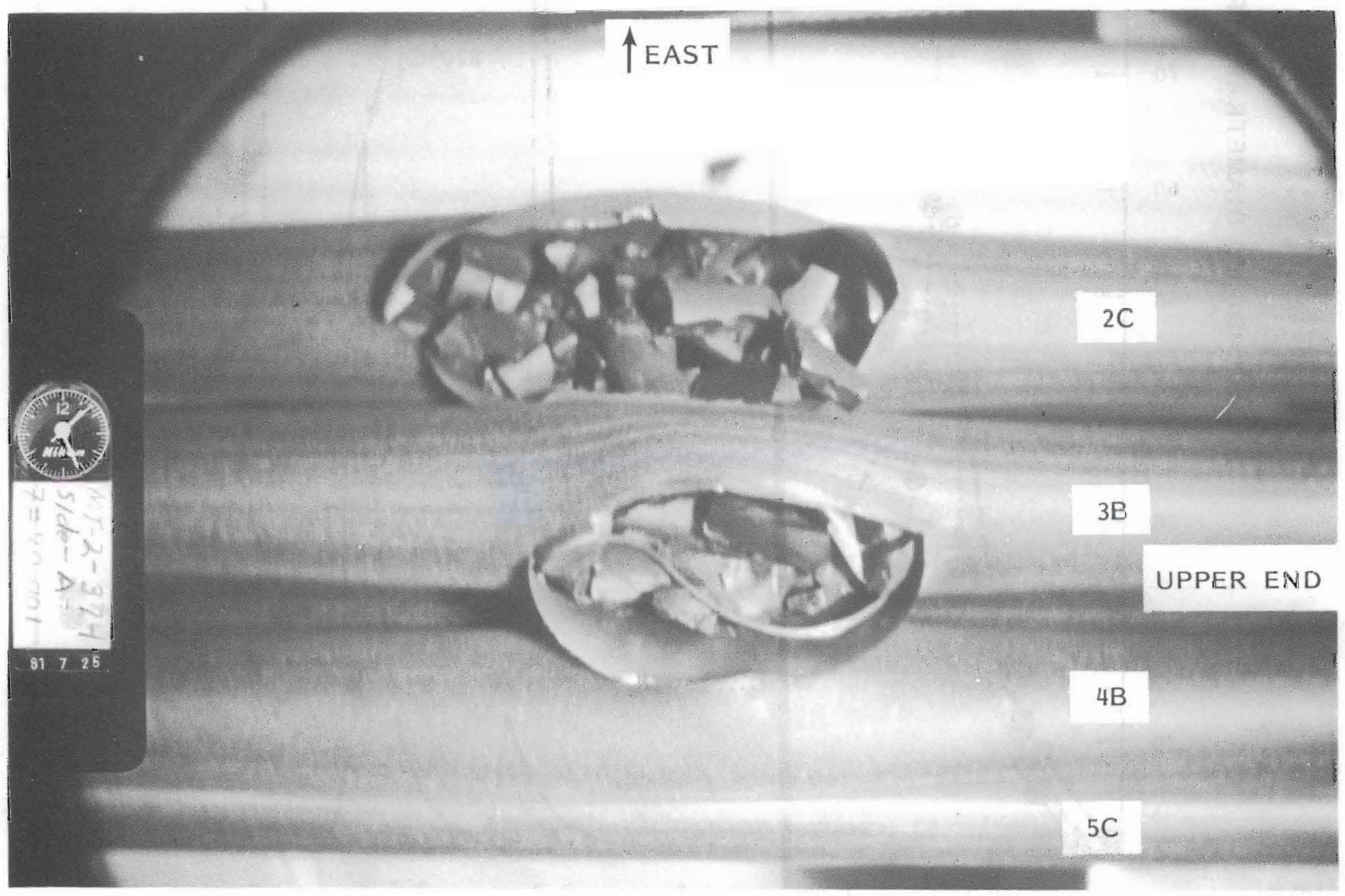

(b) NRU RODS FIGURE 25. Exposed Fuel in Test Fuel Bund?e After NRU LOCA
Test MT-2 Compared with Rod 101 1) 


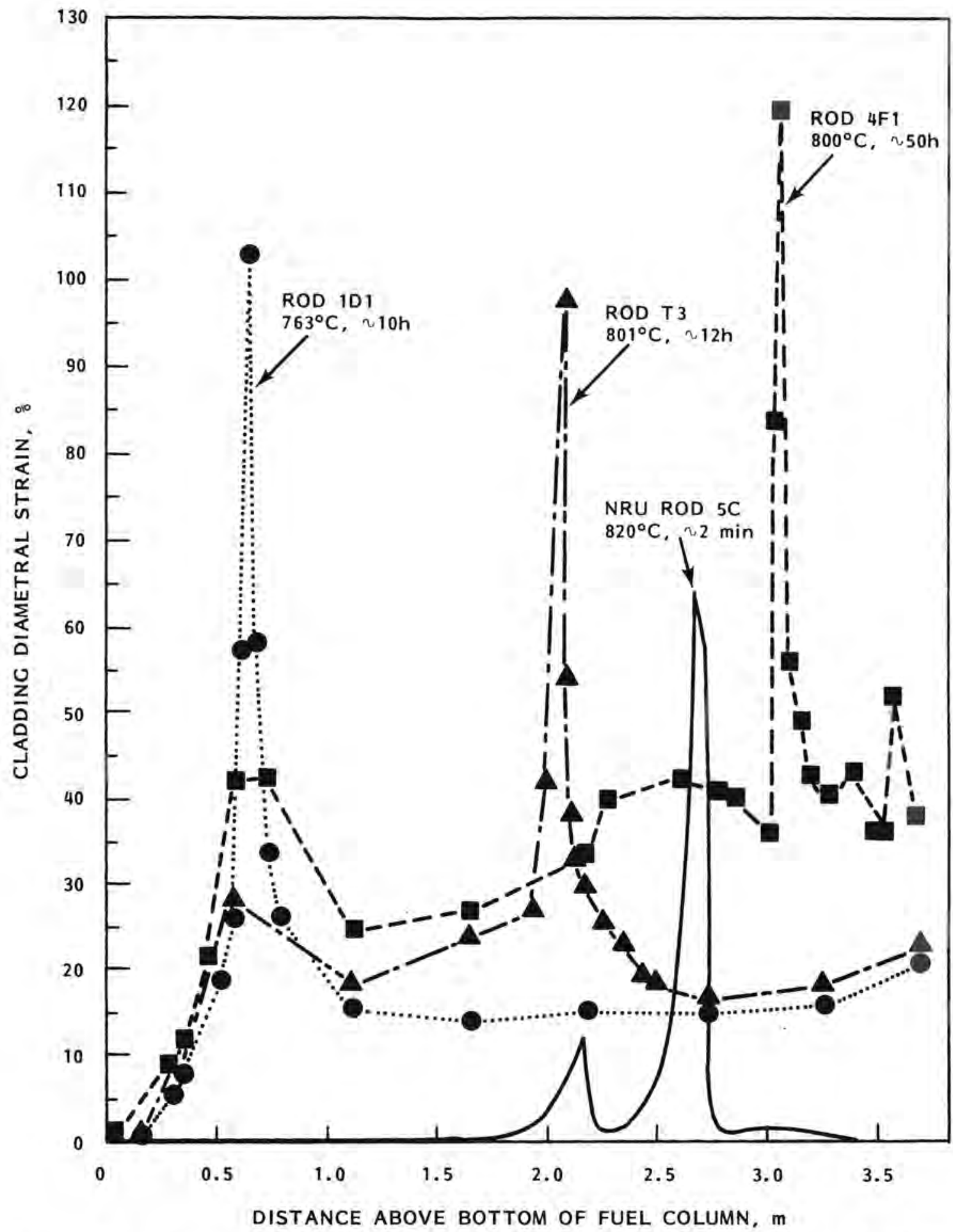

FIGURE 26. Comparison of the Cladding Diametral Strain in Rod $5 \mathrm{C}$ of the NRU LOCA Tests (4) with Those in Rods 1D1, T3, and 4F1 


\section{REFERENCES}

1. Barner, J. 0., et al. 1982. Materials Test-2 - LOCA Simulation in the NRU Reactor. NUREG/CR-2509, PNL-4155, Pacific Northwest Laboratory, RichTand, Washington.

2. Yoshimura, H. R. May 1978. "Full-Scale Simulation of Accidents on Spent Nuclear Fuel Shipping Systems." In Proceedings of Fifth International Symposium on Packaging and Transportation of Radioactive Materials, Las Vegas, Nevada.

3. Johnson, A. B., Jr., E. R. Gilbert, and R. J. Guenther. 1982. Behavior of Spent Nuclear Fuel and Storage System Components in Dry Interim Storage. PNL-4189, Pacific Northwest Laboratory, Richland, Washington.

4. Mohr, C. L., et al. 1983. LOCA Simulation in NRU - Data Report for Materials Experiment 3 (MT-3). NUREG/CR-2528, PNL-4166, Pacific Northwest Laboratory, Richland, Washington.

5. Mohr, C. L., et al. 1978. Transient Deformation Properties of Zircaloy for LOCA Simulation. EPRI NP-526, prepared for the ETectric Power Research Institute by Battelle, Pacific Northwest Laboratories, Richland, Washington.

6. Lowry, L. M., et al. 1979. Evaluating Strength and Ductility of Irradiated Zircaloy, Task 5, Quarterly Progress Report January-March 1979. NUREGTCR-0892, BMI-2034, BattelTe-Columbus Laboratories, Columbus, Ohio. 
○

0

O 